\title{
Competitive Preferences and Ethnicity: Experimental Evidence from Bangladesh*
}

\author{
Abu Siddique ${ }^{\dagger} \quad$ Michael Vlassopoulos ${ }^{\ddagger}$
}

February 2019

\begin{abstract}
In many countries, ethnic minorities have a persistent disadvantageous socioeconomic position. We investigate whether aversion to competing against members of the ethnically dominant group could be a contributing factor to this predicament. We conducted a lab-in-the-field experiment in rural Bangladesh recruiting males from the ethnic majority (Bengali) and an underprivileged ethnic minority group (Santal) that is severely discriminated against. We randomly assign participants into groups with different ethnic composition and elicit a measure of their competitiveness. We find that when compelled to compete, there are no ethnic differences in performance and that both ethnic groups perform better in ethnically-mixed groups than in homogeneous groups. We also find that the ethnic composition of the group of competitors is an important determinant of competitive entry and its effect varies by ethnic group. Members of the ethnic minority group are less likely to compete in groups where they are a numerical minority than when all competitors are coethnic, whereas the reverse is true for members of the ethnic majority group. This difference is not explained by heterogeneity in performance, risk preferences, beliefs about relative ability or various socioeconomic characteristics of individuals or of their opponents. We conclude that differences in unmeasured markers of ethnicity, such as social power and status, must underpin these differences in preferences for interethnic competition.
\end{abstract}

Keywords: Competitiveness, Group Composition, Ethnicity, Minority, Identity, Stereotypes, Lab-in-the-Field Experiment

JEL Classification: C9, C91, C93, J15

${ }^{*}$ We are very grateful to Costantine Sedikides, Thomas Gall, Zach Maniadis, Sacha Kapoor, Mirco Tonin, Pushkar Maitra, Pedro Robalo, Dongwoo Kim, and James Fenske for very thoughtful comments and discussions, as well as seminar participants at Birmingham, Rajshahi, Southampton, the Discrimination at Work Conference in Rotterdam, ACCER Workshop in Duisburg, the RES Junior Symposium at Bristol, SEEDEC at UEA, Warwick PhD Conference, Free University of Bozen-Bolzano and CAGE \& IAS Summer School at Warwick. We thank Md. Golam Faruk Sarker and Ashrai (NGO) for their support. We also thank Tahmid Hasan, Arif Hossain, Shamirul Islam and Nazmul Sakib for excellent research assistance. This work has received financial support from the ESRC, UK.

${ }^{\dagger}$ Economics, Technical University of Munich, Straubing 94315, Germany; BIGD, Dhaka, Bangladesh. Email: a.siddique@tum.de

${ }^{\ddagger}$ Economics Department, Social Sciences, University of Southampton, Southampton SO17 1BJ, UK; IZA, Bonn. Email: m.vlassopoulos@soton.ac.uk 


\section{Introduction}

A number of recent studies have found ample evidence of gender differences in competitive preferences (Croson \& Gneezy, 2009; Niederle \& Vesterlund, 2011; Niederle, 2017). ${ }^{1}$ Subsequent studies have shown that measures of competitiveness elicited experimentally can explain economic outcomes outside the laboratory such as career and educational choices, earnings and investment decisions (Buser, Niederle \& Oosterbeek, 2014; Zhang, 2013; Reuben, Sapienza \& Zingales, 2015; Berge, Bjorvatn, Pires \& Tungodden, 2015; Flory, Leibbrandt \& List, 2014). ${ }^{2}$ Like women, ethnic minorities in many countries and contexts (e.g. African Americans in the US, Roma in Europe, indigenous people in various parts of the world) also fare badly in the labor market and are lagging behind the respective ethnically dominant group in various socioeconomic indicators. Extending the insight about the explanatory power of competitive preferences for gender differences, one could conjecture that competitive preferences might help us understand the persistent disadvantageous position of ethnic minorities. That is, if members of ethnic minority groups are reluctant to compete against members of the ethnically dominant group, they might be refraining from taking actions, such as, investing in education, applying for positions of authority or accessing scarce resources that would help them elevate their socioeconomic status. A good starting point to address these issues is to examine empirically whether differences in preferences for interethnic competition exist between the majority (dominant) and minority (subordinate) ethnic groups, which is the main aim of this paper.

We conducted a lab-in-the-field experiment in rural Bangladesh, drawing participants from the ethnic majority (Bengali) and a minority group (Santal). Bangladesh is a suitable context for our purposes, as it is home to many ethnic minority/indigenous communities that do severely poorly in several socioeconomic outcomes and are subject to exploitation and discrimination by members of the ethnic majority group. ${ }^{3}$ In

\footnotetext{
${ }^{1}$ Findings from this growing literature suggest that women and men react to competition differently, with women exhibiting distaste for competition and performing less well in competitive environments (Gneezy, Niederle \& Rustichini, 2003; Niederle \& Vesterlund, 2007), while a handful of studies have further provided evidence that both women and men dislike competing against men in particular (Datta Gupta, Poulsen \& Villeval, 2013; Niederle, Segal \& Vesterlund, 2013; Geraldes, 2018; Burow, Beblo, Beninger \& Schröder, 2017).

${ }^{2}$ Zhang (2013) and Buser et al. (2014) find that students who are more inclined towards competition are more likely to take competitive high school entry exams and opt to choose prestigious study tracks. Also, exhibiting competitive tendencies in the lab has been shown to be associated with higher (expected and actual) earnings and working in high-paying industries (Reuben et al., 2015; Reuben, Wiswall \& Zafar, 2017), as well as investing more in businesses in the field (Berge et al., 2015). Finally, Flory et al. (2014) provide field experimental evidence that women are less likely to apply for jobs in which compensation is based on relative performance.

${ }^{3}$ See, for example, AIPP (2007) and Roy (2012) for unfair treatments of ethnic minorities in
} 
this environment, it is very likely that the two ethnic groups are indoctrinated from a young age to form opposing stereotypes regarding non-co-ethnic members: Santals grow up to believe that they are inferior to the majority ethnic group, while the latter are nurtured to look-down-upon the minority group. ${ }^{4}$ Consequently, this socialization process could shape the norms surrounding interethnic interactions, including attitudes towards engaging in competition with each other. Indeed, recent studies have shown that culture, socialization, the local environment, social and economic institutions and even local work experiences play significant role in the shaping of competitive preferences (Gneezy, Leonard \& List, 2009; Booth \& Nolen, 2012; Cárdenas, Dreber, Von Essen \& Ranehill, 2012; Andersen, Ertac, Gneezy, List \& Maximiano, 2013; Leibbrandt, Gneezy \& List, 2013; Zhang, 2018; Booth, Fan, Meng \& Zhang, 2019). We, thus, expect that given the ethnic background of our setting, the two ethnic groups will have developed tastes for interethnic competition that mirror the clear hierarchical relationship and the imbalance of power that exists between them. Another possibility that we consider is that the years of oppression will have shaped the competitive preferences of the ethnic minority group to have rendered them less competitive overall, regardless of the identity of the competitor.

In the experiment, we randomly assign participants into groups of six in a faceto-face setup, and we obtain a measure of their competitive preferences following the design of Niederle \& Vesterlund (2007). In particular, we first ask our participants to perform a simple manual task (separating lentils from rice) under a piece-rate and then a competitive compensation scheme (winner-take-all tournament). In a third stage, we ask them to select their preferred compensation scheme, which reveals their preferences with respect to competition. Our experimental design involves three treatment groups: a homogeneous group where subjects are all co-ethnics, a group where ethnic minority people are a numerical minority (2 to 4), and a 'reversed' group where ethnic minority people are a numerical majority (4 to 2). Ethnicity in our context is easily identifiable by physical markers and hence is unambiguous. Thus, even though ethnic composition was never discussed in the course of the experiment, our subjects could easily identify the ethnicity of their group members and hence the ethnic composition of their group. We expect that while there should not be an overall difference in competitive inclination towards co-ethnics across the two ethnic groups, in ethnically diverse groups, we would

Bangladesh. We describe these in detail in Section 2.

${ }^{4}$ Tribal minorities are seen as 'inferior races' by the ethnic majority (Hardiman, 1987; Bal, 2007), which is believed to be a product of multi-generational socialization process (Barndt, 2007). On children internalizing socialized lies regarding superiority and inferiority, Joseph R. Barndt (2007, p. 125) says, "...If I am consciously and unconsciously taught from the moment of my birth that I am inferior (superior) and a member of an inferior (superior) race, I will believe and act according to this message." 
see ethnic differences in preferences for engaging in competition, with the minorities showing increased aversion to competing the more the members of the majority group in the group of competitors.

We find that in the compulsory tournament stage, there are no ethnic differences in performance and that both ethnic groups perform better in ethnically-mixed treatment groups than in homogeneous treatment groups. This suggests that participants are more willing to internalize the negative externality their effort imposes on a group of co-ethnics under a relative performance incentive scheme and is consistent with previous lab and field evidence of an in-group bias in people's social preferences (Bandiera, Barankay \& Rasul, 2005; Chen \& Li, 2009). We also find that ethnic composition of group of competitors is an important determinant of self-selection into the competitive scheme is stage 3. Despite the fact that overall competitiveness is similar across ethnic groups, group composition affects tournament entry decisions by members of the two ethnic groups differently. When compared to choices made in homogeneous treatment groups, members of the ethnic minority show a distaste for competition in groups where they are a minority, whereas ethnic majority members demonstrate a preference for competition in groups where they are a minority. To be more precise, ethnic minorities are 25 percentage points less likely to compete in groups where they are a minority (decrease of 60 percent) than when all competitors are co-ethnic, whereas ethnic majorities are 22 percentage points more likely to compete in groups where they are a minority (increase of 80 percent) than when all competitors are co-ethnic.

We show that these patterns are not explained by heterogeneity in task proficiency, risk preferences, beliefs about relative ability on the task, or a host of demographic characteristics. Hence, our study points to participants from the two ethnic groups having a genuinely different attitude toward entering competitive environments in which the pool of potential competitors is multiethnic. Delving further into whether the mechanism behind this relates to the substantial differences in socioeconomic status across the ethnic groups, we explore whether the differences in interethnic competition remain even when we take into account the income and land ownership of competitors, which given the degree of familiarity among the participants is plausibly known. We do not find this to be the case, leading us to conclude that it must be ethnic differences in unmeasured dimensions, such as social power and status, that drive these patterns.

Beyond the literature on competitive preferences mentioned above, our study connects to the literature on social identity, the formation of stereotypes and their impact on behavior that has a long history in psychology and sociology (Tajfel, 2010; Greenwald \& Banaji, 1995; Steele \& Aronson, 1995; Shih, Pittinsky \& Ambady, 1999). In economics, 
the seminal paper by Akerlof \& Kranton (2000) introduces a theoretical framework that connects social identity based on social differences, e.g. race, class, ethnicity, etc. with economic behavior and outcomes. More recently, experimental studies have shown that making ethnic or racial identity salient affects risk and time preferences (Benjamin, Choi \& Strickland, 2010), that induced group identity affects social preferences (Chen \& Li, 2009), and that making nationality salient induces coordination among individuals who share common nationalities (Stoddard \& Leibbrandt, 2014). Furthermore, a few more recent studies have shown experimentally that social identity can affect the performance of a deprived group or the treatment that they receive from out-group members. In particular, two related studies of caste in India find that publicly revealing the social identity of the lower-caste diminishes their performance in a cognitive task (Hoff \& Pandey, 2006, 2014), while Afridi, Li \& Ren (2015) find similar effects for rural workers in China. Finally, Fershtman \& Gneezy (2001) find that behavior in experimental games (trust, dictator, and ultimatum games) conducted with opponents from different ethnic groups in Israel to be consistent with ethnic stereotypes. Our results extend this line of research by showing that ethnic group identity (majority or minority) matters for one's willingness to engage in interethnic competition.

This paper is organized as follows. Section 2 provides background on the ethnic minority group studied. Section 3 describes the design of our study and the hypotheses to be tested. In Section 4, we present our results. Section 5 concludes.

\section{Background on Ethnic Groups in Bangladesh}

In Bangladesh, besides the ethnic majority group (Bengali) there are around 45 different indigenous/tribal communities that constitute about 2 million of the country's total population of 150 million, including many of the country's extreme poor (IMF, 2013; People's Republic of Bangladesh, 2016). These groups are culturally, racially, ethnically and linguistically distinct from the majority Bengali population, and are the most persecuted of all minorities. ${ }^{5}$ They have restricted access to basic social services such as health, food and nutrition, education, employment, justice and politics (AIPP, 2010; Roy, 2012; IMF, 2013), and are subject to extortion by the ethnic majority land grabbers (Roy, 2012). They also receive unfair prices for their products (AIPP, 2010) and have been at the receiving end of crimes for generations (Roy, 2012; D'Costa, 2014). Illegal dispossession of tribal people from their lands is widespread (in both Bangladesh

\footnotetext{
${ }^{5}$ Tribal people in India face similar treatment by the ethnic majority population (Kijima, 2006; Shah, 2007; Bhengra, Bijoy \& Luithui, 1999).
} 
Figure 1: Map of Bangladesh

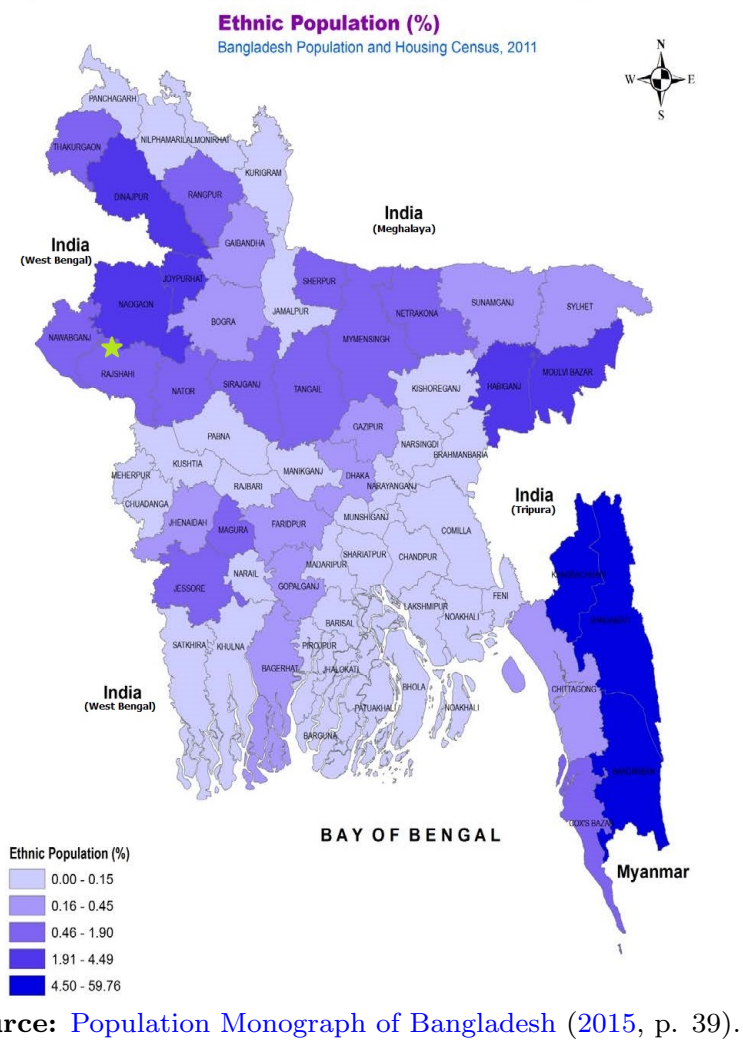

and India) where the dispossessed receive nominal to no compensation in some instances, even though the State Acquisition and Tenancy Act 1950 (Section 97, 1950) strictly prohibits alienation of such lands. Figure 1 illustrates the geographic concentration of the tribal population in Bangladesh.

Ethnic minority participants in our study are entirely comprised of people who identified themselves as Santals - the second most populous tribal community in Bangladesh. ${ }^{6}$ Santals predominantly reside in Rajshahi, Dinajpur, Chapai Nawabganj and Borgra districts in the north-western region of Bangladesh, although the largest portion of Santals lives in Jharkhand of India (Ali, 1998; Cavallaro \& Rahman, 2009; Ahmed, 2010). Like the ethnic majority people in Bangladesh, Santals also follow patriarchy (Upadhyay \& Pandey, 1993). They have their own tribal religion (worship a Supreme Deity called Thakur) (Risley, 1891), although many also follow Hinduism or Christianity; the ethnic majority Bengali, however, follow Islam (86.6 percent) (People's Republic of Bangladesh,

\footnotetext{
${ }^{6}$ Three of the most populous tribal communities in Bangladesh are the Chakma, the Marma and the Santal; the former two are usually known as 'hill-people' (live in high altitudes) and the latter is known as 'plains-dwelling' (live in the plains).
} 
2016). The majority of Santals are involved in farming, working for landlords as day laborers as most of them are landless (Ali, 1998). They speak Santali language within their community, though they learn to speak Bangla to communicate with the ethnic majority population. One of the first and oldest accounts of ethnic origins and physical characteristics of Santals by Herbert H. Risley (1891, p. 225) describes them as "pure Dravidians", having very dark and "...almost charcoal like" complexion, "large mouth" and "thick lips". 7 They are among the poorest tribal groups and are severely disadvantaged in terms of employment, land ownership and education (Cavallaro \& Rahman, 2009; Samad, 2006). In schools, Santal children face discrimination and physical abuse from their teachers and classmates, e.g. Bengali classmates avoid sitting beside their Santal peers in classrooms, which results in dropouts from schools at a very young age (Samad, 2006; Sarker \& Davey, 2009). Their lack of literacy is considered one of the major reasons for easy forgery and illegal dispossession by the ethnic majority population (Sarker \& Davey, 2009). In this regard, Cavallaro \& Rahman (2009, p. 204) stated:

"... in Bangladesh the Santals face discrimination from the majority community, and the Bangla speaking population and the government has done little to help the Santals protect themselves from the continuous land grabbing and dispossessions. Indeed there is a feeling among the minority people of Bangladesh that they are continuously being overlooked in favor of the majority group in all facets of life. These include employment opportunities and education. These issues have led to a deep sense of social insecurity."

\section{The Experiment}

\subsection{Recruitment and Procedures}

We conducted a lab-in-the-field experiment (Gneezy \& Imas, 2016) in the summer of 2016 in six different multi-ethnic villages in the Rajshahi district of rural Bangladesh. We recruited our participants from the two distinct ethnic groups that populate these villages: the ethnic majority Bengali and the ethnic minority Santal. In total, 252 male adults of equal proportion from the two ethnic groups participated in our experiments. ${ }^{8}$

\footnotetext{
${ }^{7}$ These features are different than that of the ethnic majority, which makes their ethnicity easily identifiable. See Risley (1891, p. 224-235) for a more detailed explanation of physical characteristics and ethnic origins of Santals. Also, see Orans (1965) and Ali (1998) for more details on customs and lifestyle of Santals.

${ }^{8}$ We opted to recruit only male participants because studying both ethnic and gender differences in competitiveness would have required a much larger sample. The question of whether the preferences for interethnic competition that we uncover in our male sample carry over to females is an interesting one that we leave for future research.
} 
Our subjects came from fourteen different multi-ethnic villages; although multi-ethnic, segregation within villages is commonplace, as Santal/Bengali houses cluster around their co-ethnics (each cluster is known as a para) (Ali, 1998). In these villages, 19 percent of the population (and households) are Santals whereas the rest are the ethnic majority Bengali. ${ }^{9}$ Also, exogamy or interethnic marriages are not prevalent. People tend to work collectively with their co-ethnics, i.e. generally with family, extended family or relatives, but not with their non-co-ethnic fellow villagers. Since all villagers are considerably poor and do not posses the capacity to hire others for work, members of one ethnic group do not employ members of the other; hence, personal and professional attachments are trivial among members of the two ethnic groups.

Participants were recruited through in-person advertisements: experiment helpers of both ethnicities visited random marketplaces, houses, and crop fields, and advertised our experiment by reading out an experiment advert. Through the advert, people were informed about the pecuniary incentives involved, the conditions for participation and the location for registration. Initial registration was carried out in seven different locations where we also set up our laboratories. During registration, participants were only asked to provide their full name, age, and ethnicity. Prospective subjects also had the option to choose their preferred location and time for a session from seven different location options. All people chose their initial registration location as their preferred location for their experiment session. This was expected because all seven of our locations are quite far from one another, which was intentionally done to minimize contamination. Furthermore, people were also expected to know each other because our villages are small, so some degree of social networks within and across ethnic groups was expected.

After the initial registrations were complete, potential subjects were given a piece of paper that contained their name, age, and ethnicity, which they were asked to bring to the laboratory. Registration was done on a first-come-first basis, so people who were registered were all invited to the experiment and any 'extra' arrivals at the registration desk were asked to go to our next registration location on another day to register for a session. In total, 296 people were initially registered (four extra for each session). In the experimental sessions, participants were also enrolled in the lab on a first-come-first basis. Four over-recruited individuals for each session were asked to leave with a show-up fee. All people who initially registered arrived at the lab on time.

The location of each lab was a central place in the village, e.g. either primary schools, churches or public office spaces. Upon arrival, participants were asked to form a queue outside the lab, on a first-come-first basis. Five minutes prior to the experiment's

\footnotetext{
${ }^{9}$ We obtain these figures from the Household Survey Report 2012 assembled by Ashrai, an NGO.
} 
start time, participants were asked to enter the lab and report to the enrolment table, one by one. At enrolment, they were asked to hand in their initial registration paper as well as state their full name and ethnicity, and then based on that information, they were asked to pick their ID numbers from a bowl. In order to ensure that we had the desired number of Santals and Bengalis in each group, we prepared two bowls with ID numbers; one for Santals, in which IDs were matched with seats that were only for Santal participants, and another for Bengali participants. ${ }^{10}$ After randomly picking their ID numbers, they were taken to their respective seats by our assistants.

\subsection{Experimental Design}

The experiment follows the standard experimental protocol of eliciting competitive preferences developed by Niederle \& Vesterlund (2007). We introduce two main changes: (i) we implemented a different task that is more appropriate for the participant pool in hand, and (ii) we manipulated the ethnic composition of the groups to which participants were randomly assigned to, in order to test for whether the ethnic affiliation of competitors matters for willingness to compete.

The task used in this experiment was separating red lentils from white rice grains. Specifically, each person received a bowl with a mixture of rice and lentils, and another empty bowl to place the separated lentils. ${ }^{11}$ We used red colored bowls for separated lentils so that color of lentils matches with the bowl and make it difficult for our subjects to count/guess the other person's score. Each separated lentil won participants points, while each rice grain picked along with lentils made them lose points. Hence, performance is measured by the number of lentils minus any rice grains placed in the red bowl. This task was selected because it was very simple to explain and implement. Since most of the participants were uneducated and from the unskilled labor force, with the majority of them working as farmers, a task involving everyday grains and pulses was comprehensible to our average participant. In addition, this task was ethnicity neutral (as was found in a pilot and further established in the first stage of the experiment), so no differences in ability were expected across ethnicity. Furthermore, our subjects were all men coming from patriarchal societies where women are mostly considered homemakers and are involved in cooking, so men were expected to know very little about cooking and hence sorting rice and lentils. So, this task was completely new to our subjects, as also confirmed in the exit survey. See Appendix B for a detailed explanation of the task

\footnotetext{
${ }^{10}$ We used the same colored bowls for both ethnicities to avoid suspicion while picking ID numbers.

${ }^{11}$ The mix was always one-fifth lentils and four-fifth rice in terms of volume. Since lentils are smaller and lighter than rice grains, this ratio gave us a near fifty-fifty ratio of numbers of rice and lentils in each bowl.
} 
and experimental instructions.

Each session lasted about ninety minutes and was attended in equal proportions by members of the two ethnic groups. Therefore, by design, our sample is balanced across ethnicity in all sessions and the experiment overall.

Participants were assigned to groups of six and each session had four groups in total. Thus, twenty-four participants in total participated in each session, of which half were Santals and half Bengalis. ${ }^{12}$ In the lab, there were four big rectangular tables with six chairs around, so each group was assigned to a table. By varying the ethnic composition of a group, our design involves three group treatments: homogeneous, majority, and minority. A homogeneous treatment was composed of participants from a single ethnicity, i.e. either they had six Santals or six Bengalis in the group. Mixed treatments comprised participants of both ethnic identities. They either had two Santals and four Bengalis (i.e. a group where Santals are a numerical minority) or four Santals and two Bengalis (i.e. a group where Santals are a numerical majority). Moreover, in mixed treatments, a minority member of that group was always seated next to or in front of their ethnic peer. For example, a Bengali in a minority treatment was always seated next to or in front of another Bengali. ${ }^{13}$ Figure 2 depicts the arrangement of participants and groups in a session. ${ }^{14}$

To sum up, in each session, there were two homogeneous treatment groups, one with all Santals and another with all Bengalis; and two mixed treatment groups, one with Santals as a numerical minority and another with Santals as a numerical majority. ${ }^{15}$ These ethnic compositions were never discussed with or revealed to participants, and the ethnicity of participants was never made salient before or during the experiment. However, participants could see each other and hence could identify the ethnicity of their group members. Later, in the exit survey, we asked our subjects about ethnic identities and compositions of their groups to ensure correct identification.

After having seated, participants were asked to remain silent and then the in-

\footnotetext{
${ }^{12}$ The only exception was one session where there were twelve participants in mixed treatments: a Santal-majority (where Santals are a numerical majority) and a Santal-minority (where Santals are a numerical minority).

${ }^{13}$ Only exception was in group 1 in the first session where the numerical minority members were not seated adjacently. This occurred due to a swap of two ID numbers in the ID bowls by mistake.

${ }^{14}$ The face-to-face setup was necessitated by the desire to make the ethnic identity of group members salient in an as neutral and natural way as possible that would not induce experimenter demand effects. This could pose a problem if in some treatments participants know each other well, whereas in others they do not. Using participants' self-reported answers on whether they could correctly name each of their group members, we cannot reject the null hypothesis that the distribution of known group members' names is the same across all treatments for the whole sample $(p=0.498)$, for Santals $(p=0.440)$ and for Bengalis ( $p=0.768)$ using a Pearson's Chi-square test.

${ }^{15}$ Only in one session there were two mixed groups.
} 
Figure 2: Group Composition in Each Session
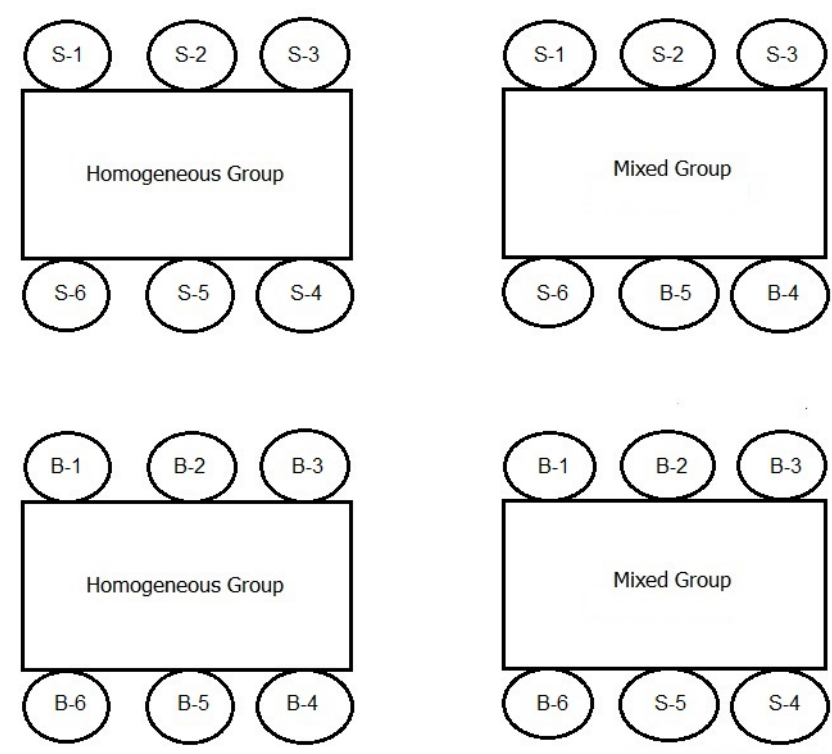

Note: $\mathrm{S}$ is for Santal and B is for Bengali; Numbers 1-6 correspond to the last digit of a subject's ID.

structions were read aloud. All instructions were translated from English into the local common language, Bangla, and were also back-translated to evaluate the equivalence of meaning between both instructions. ${ }^{16}$ After having read out the instructions, participants were asked to raise hands if they had any questions or doubts. To ensure participants had understood all compensation schemes perfectly, at the end of each instruction, a range of frequently asked questions (FAQs) and their answers were also read out to participants. For example, a FAQ in stage 1 instruction was "How much will you earn per lentil?" with the answer being "5 Taka". Please see Appendix B for all instructions and FAQs. They were advised to listen to them very carefully and were told to raise hands if they had any questions or doubts. Then, after answering any questions, the experimenter asked the participants to rub their hands twice and then gave the signal to start the task. After 60 seconds, participants had to stop performing the task and immediately put their hands up (the same as when someone is called to surrender). ${ }^{17}$ Participants were informed at the start of the experiment that they would

\footnotetext{
${ }^{16}$ All Santal participants were fluent in Bangla, so only Bangla instructions were used. We confirmed their fluency and their understanding of Bangla during the initial registration.

${ }^{17}$ The gesture of rubbing hands before performing the task ensured that no one was cheating by hiding lentils in their hands. Likewise, putting hands up after completing the task ensured all subjects took equal time. Also putting hands up diverted their attention towards performing the action and look at others who have done it, and away from checking other group members' scores right after completing the task, which gave our assistants enough time to move the bowls away from their sights.
} 
perform the task in three stages and one of these stages would be randomly chosen for payment. Additionally, participants received detailed instruction on each stage only prior to performing the task in that stage and were never given feedback on absolute or relative performance between stages. At the end, participants were told how well they had done in each stage, but they were not informed about their relative performance. The incentive structure of each stage is laid out below.

- Stage 1: Piece-rate Participants performed the task for 60 seconds and received a piece rate of 5 Taka for each separated lentil. ${ }^{18}$

- Stage 2: Tournament Participants performed the task for 60 seconds. Only the group member with the highest lentil count would receive payment, while others in the group would receive no payment. For each separated lentil (net score) the winner received 30 Taka. In the case of ties, winning amounts were divided equally among winners.

- Stage 3: Choice Before performing the task, participants chose which of the two compensation schemes would be applied to their performance in this stage. If a participant were to choose piece-rate, then he would receive 5 Taka for each separated lentil. However, if a participant chose tournament, then he would receive 30 Taka for each separated lentil only if his stage 3 score exceeded the stage 2 scores of his five group members.

Note that performance of those who opted to compete in stage 3 was evaluated against those who had already competed under the competitive compensation scheme in stage 2. Therefore, beliefs regarding choices of others in stage 3 would not affect someone's decision to enter into competition. Moreover, choice of entering into competition would not affect payments of other participants, which ruled out the possibility of imposing negative externalities on others by winning in stage 3 (Niederle \& Vesterlund, 2007). In addition, it also ensured that consequences, such as fear of being punished by other group members outside the lab would not affect choice.

It should also be mentioned that all assistants were male Bengalis working as anthropology researchers (who were well respected among villagers) from a local public university in collaboration with a local NGO, which was also well respected and trusted

\footnotetext{
${ }^{18}$ The Bangladeshi currency is called Taka. USD 1 was equal to 80 Taka during the time of the experiment.
} 
for providing micro-loans, eradicating poverty and fighting for human rights for the needy. We can thus be confident that behavior of Santals would not be affected by fear of being discriminated by experimenters in terms of payment.

\subsection{Confidence and Risk Preferences}

The decision to enter into competition in stage 3 could be affected by individuals' beliefs about their relative performance in their group. So, to control for this we elicited these beliefs for performance in stage 2 , the compulsory tournament stage, paying participants for correct reports. ${ }^{19}$ Another important factor that might affect one's willingness to compete in stage 3 is attitudes towards risk. We elicited risk attitudes through a standard risk game (Gneezy \& Potters, 1997; Gneezy et al., 2009), immediately after completing stage $3 .^{20}$

\subsection{Exit Survey and Payment}

After completing the risk game, participants were asked to go to an assistant to complete an exit survey. For each subject, we obtained data on their socioeconomic background and some other individual level data, namely marital status, the level of intercultural competence, land possessions, handedness and so on. In addition to money earned from the games, each subject received a show-up fee of 100 Taka. For 90 minutes

\footnotetext{
${ }^{19}$ Immediately after stage 2 , we randomly asked our participants to go to the registration desk, one by one, where we showed them a picture with six heads. Heads were arranged vertically where the topmost head represented the 'best' (or rank 1) and that at the bottom represented the 'worst' (or rank 6) performer in stage 2. Participants only had to point to a head with their finger, and then return to their respective desks. They received 50 Taka if their guesses were correct and no money if incorrect. See Appendix B for the heads' arrangements. We decided to conduct the guessing game immediately after the compulsory tournament in order to obtain more accurate beliefs about their stage 2 performance.

${ }^{20}$ In this one-shot independent game, we asked our subjects to bet a proportion $[0,100]$ of their endowment of 100 units, or 20 Taka, into a lottery. The bet had a fifty-fifty chance of winning which was determined by a coin toss. Subjects received six times the amount invested if there was a head but lost the bet money if there was a tail. If the proportion of the bet was less than 100 percent, then subjects received the remaining un-bet amount, irrespective of the coin-toss outcome. Following Gneezy et al. (2009), stakes in the risk game overlap the stakes in the competitiveness game, wherein the initial endowment is equivalent to the payment for separating four lentils under the piece-rate scheme. Likewise, the maximum payoff is equivalent to the payment for separating the same amount of lentils under the tournament scheme. After the instruction was read aloud, subjects were asked to raise hands if they had any queries. Then, after clearing any confusions, the experimenter asked the subjects to go to the registration desk, one by one, in random order, where they were asked to state their risk choices. The coin toss was performed immediately after a bet was placed and the outcome of the toss was always confirmed by the subject. See Appendix B for the Risk Game instructions. Registration desks were located outside the lab room (though on few occasions it was inside when the room was large enough), so other subjects could not see or hear any risky choices and outcomes that were made at the desk. Hence, choices for risky bets were individual decisions that did not affect decisions or payoffs of others, which is analogous to the mechanism of making choices in stage 3 .
} 
of their time, our average subject earned about 1.5 times more (320 Taka) than their average daily income (207 Taka) and six times more than the daily national minimum wage (Minimum Wage Board Bangladesh, 2015). At the end of the experiment, participants were paid in cash, individually and in private.

\subsection{Hypotheses}

We formulate three hypotheses. The first hypothesis concerns performance in the first stage of the experiment. Since our study is concerned with ethnic differences in preferences for competing on a task, it is important that the chosen task is not associated with any ethnic stereotype attached to a specific group. Indeed, we selected a simple manual task that was expected to be novel and neutral to participants of both ethnicities and hence we do not expect (and pretests confirmed this) to see any ethnic differences in performance in the first stage of the experiment.

Hypothesis 1: There is no difference in performance across ethnic groups in the piece-rate stage.

Our second hypothesis concerns performance in the tournament stage. Here, we expect participants to perform differently in homogeneous and mixed treatments. This is because under a tournament scheme an individual's effort negatively affect others, so subjects are more likely to internalize the negative externality their effort imposes on a group of co-ethnics as opposed to that of non-co-ethnics (Bandiera et al., 2005).

Hypothesis 2: In the tournament stage, performance would be lower in homogeneous treatments than in mixed treatments.

Our third and main hypothesis, concerns behavior in the third stage. Given the power structure that connects the two ethnic groups described in section 2, we expect the ethnic minority Santals to respond differently to the ethnic composition of potential competitors than the ethnic majority Bengalis. This conjecture is supported by research in social psychology that has explored the role of power and status in intergroup behavior and relations (Tajfel, 1982; Keltner, Gruenfeld \& Anderson, 2003; Brauer \& Bourhis, 2006; Fiske, Dupree, Nicolas \& Swencionis, 2016). The relative power of a group affects how its members are perceived and perceive others and has impact on intergroup behavior especially when there are stark status and power differences across groups. Indeed, experimental evidence suggests that low power and low status minorities tend to show out-group favouritism and low own group valuation (Sachdev \& Bourhis, 1991; Jost, 
Banaji \& Nosek, 2004; Tsutsui \& Zizzo, 2014). In our context involving longstanding inequalities between the two ethnic groups, we expect the Santals to have internalized their position in the power hierarchy and to act with deference toward the dominant group, including showing reluctance to compete against them. This hypothesis is also consistent with the evidence from the literature on gender differences in competitive preferences, which has found that the gender of a competitor significantly affects one's inclination towards competition (Booth \& Nolen, 2012; Datta Gupta et al., 2013; Geraldes, 2018; Burow et al., 2017).

Hypothesis 3: Competitive choice depends on the ethnic composition of the group of competitors: (i) Santals would be less willing to compete in mixed treatments; (ii) Bengalis would be more willing to compete in mixed treatments.

An alternative possibility - that draws on the literature on endogenous formation of preferences (Bowles, 1998) and more specifically on recent studies that show that socialization and work environment can shape preferences for competition (Gneezy et al., 2009; Leibbrandt et al., 2013) - is that the type of social structure that Santals have faced for generations has shaped their preferences for competition in a fixed manner, rendering them less willing to compete than ethnic majorities, regardless of who they are competing against. This perspective is also related to previous findings that social identity has impact on the performance of socially underprivileged groups (Hoff \& Pandey, 2006, 2014; Afridi et al., 2015). This leads us to formulate an alternative hypothesis 3 :

Alternative Hypothesis 3: Santals would be less competitive than Bengalis irrespective of the ethnic composition of the group of competitors.

We test these hypotheses using the design laid out earlier in this section.

\section{Results}

\subsection{Participant Summary Statistics}

Table 1 presents summary statistics of the participants' characteristics that we collected through the exit survey by ethnic group. The average age of our participants is around 36 years, the average education attainment is in the range of 5-6 years, and around 80 percent of the participants were married at least once. None of these characteristics is significantly different across the two ethnic groups. However, the average daily income and land possessions of Bengalis are significantly higher than those of San- 
tals. It means that, as expected, Santals are rather poorer and from a lower social class, as land holdings are good indicators of one's social status in a village (Rao, 2001). Another good indicator of socioeconomic status is one's family background. Santal parents are significantly less educated and their fathers' earn less than Bengali fathers, while the opposite is true of their mothers. ${ }^{21}$ Note, however, that these comparisons rely on information on parental income reported by only about half of participants.

With regards to the occupation of participants, around 60 percent of Bengalis and 80 percent of Santals engage in farming; this difference is statistically significant according to a Pearson's Chi-Squared test (CS-test hereinafter) $(p<0.01)$. The rest are either students, owners of small businesses or working in other non-farming areas such as weaving baskets, making bamboo furniture and so on. In terms of income, farmers earn significantly less than non-farmers according to a two sided Mann-Whitney U test (MW-test hereinafter) $(p<0.01) .{ }^{22}$

Almost all participants were able to correctly identify the ethnicity of members in their group and hence the ethnic composition of their group, ${ }^{23}$ while around 50 percent of our subjects knew all five names of their group members and around 80 percent knew at least four of them. There is no significant difference in these measures across ethnic groups (MW-test $p=0.57$ and $p=0.70$ respectively). We also asked participants some questions to assess their knowledge of the other ethnic group's culture. We call this the level of intercultural competence (Fantini, 2010). ${ }^{24}$ There is a significant difference in intercultural competence across ethnic groups (MW-test $p<0.01$ ), with the Santals displaying significantly better knowledge about their non-co-ethnic peers. All background characteristics, and in particular the ones that differ across ethnicity that we have underlined here, will be directly controlled for in our regression analysis.

We next turn to experimentally elicited characteristics. In terms of beliefs regarding relative performance in the tournament stage, we compute the perceived probability of winning the tournament in stage 2 following Sutter, Glätzle-Rützler, Balafoutas \& Czermak (2016). We construct a dummy variable which equals 1 if a subject has reported

\footnotetext{
${ }^{21}$ This difference may be explained by the fact that Bengali women (who are Muslims) are mostly homemakers and hence might engage in paid-work less than Santal women.

${ }^{22}$ It should be noted that, since students have no income and are better educated than individuals who are working, income and education have a negative relationship in our sample. In addition, the majority of farmers work as day laborers for a fixed daily wage, which is independent of educational attainment.

${ }^{23}$ Only three participants could not identify the ethnicity of at least one of their group members. Excluding these three participants from our analysis does not affect the main results of the paper.

${ }^{24}$ Our questions are a very simplified version of Fantini's intercultural competence assessment questions, focusing only on the 'awareness dimension' of individuals. During the exit survey, we asked four simple questions regarding the opposite culture and produced a score from 0 to 1 for each participant, by assigning 0.25 to each correct answer.
} 
Table 1: Participant Characteristics and Beliefs

\begin{tabular}{|c|c|c|c|c|c|}
\hline $\begin{array}{l}\text { Individual } \\
\text { Characteristics \& Beliefs }\end{array}$ & $\begin{array}{l}\text { Bengali Mean } \\
\quad(\text { Std. Dev. })\end{array}$ & $\begin{array}{l}\text { Santal Mean } \\
\quad(\text { Std. Dev. })\end{array}$ & $\begin{array}{c}\text { MW-test } \\
p \text {-values }\end{array}$ & $\begin{array}{c}\text { T-test } \\
p \text {-values }\end{array}$ & $\mathbf{N}$ \\
\hline Age & $\begin{array}{c}34.59 \\
(13.95)\end{array}$ & $\begin{array}{l}37.04 \\
(14.15)\end{array}$ & 0.106 & 0.167 & 252 \\
\hline Education & $\begin{array}{l}5.58 \\
(4.57)\end{array}$ & $\begin{array}{l}5.37 \\
(4.58)\end{array}$ & 0.626 & 0.711 & 252 \\
\hline Profession & $\begin{array}{c}0.58 \\
(0.50)\end{array}$ & $\begin{array}{c}0.77 \\
(0.42)\end{array}$ & 0.001 & 0.001 & 252 \\
\hline Daily Income & $\begin{array}{l}232.9 \\
(200.5)\end{array}$ & $\begin{array}{l}179.9 \\
(77.61)\end{array}$ & 0.059 & 0.007 & 250 \\
\hline Land Possession & $\begin{array}{l}17.89 \\
(39.65)\end{array}$ & $\begin{array}{l}12.07 \\
(33.40)\end{array}$ & 0.049 & 0.209 & 252 \\
\hline Marriage & $\begin{array}{l}0.79 \\
(0.41)\end{array}$ & $\begin{array}{l}0.83 \\
(0.37)\end{array}$ & 0.337 & 0.338 & 252 \\
\hline Mother's Education & $\begin{array}{l}2.43 \\
(2.96)\end{array}$ & $\begin{array}{l}0.56 \\
(1.75)\end{array}$ & 0.000 & 0.000 & 211 \\
\hline Father's Education & $\begin{array}{c}2.51 \\
(3.33)\end{array}$ & $\begin{array}{l}1.54 \\
(3.02)\end{array}$ & 0.021 & 0.033 & 201 \\
\hline Mother's Income & $\begin{array}{c}583.3 \\
(1,571)\end{array}$ & $\begin{array}{c}1,551 \\
(1,908)\end{array}$ & 0.000 & 0.002 & 138 \\
\hline Father's Income & $\begin{array}{l}6,578 \\
(3,692)\end{array}$ & $\begin{array}{c}4,434 \\
(2,205)\end{array}$ & 0.000 & 0.000 & 111 \\
\hline Mother's Profession & $\begin{array}{l}0.17 \\
(0.38)\end{array}$ & $\begin{array}{l}0.53 \\
(0.50)\end{array}$ & 0.000 & 0.000 & 211 \\
\hline Father's Profession & $\begin{array}{c}0.89 \\
(0.31)\end{array}$ & $\begin{array}{c}0.93 \\
(0.25)\end{array}$ & 0.320 & 0.315 & 188 \\
\hline Parents' Income & $\begin{array}{l}5,549 \\
(4,411)\end{array}$ & $\begin{array}{l}4,957 \\
(3,890)\end{array}$ & 0.437 & 0.391 & 145 \\
\hline Parents' Education & $\begin{array}{l}4.86 \\
(5.53)\end{array}$ & $\begin{array}{l}1.99 \\
(4.25)\end{array}$ & 0.000 & 0.000 & 212 \\
\hline IC Competence & $\begin{array}{l}0.48 \\
(0.27)\end{array}$ & $\begin{array}{c}0.88 \\
(0.21)\end{array}$ & 0.000 & 0.000 & 252 \\
\hline Know Other Participants' Name & $\begin{array}{c}4.31 \\
(0.86)\end{array}$ & $\begin{array}{c}4.34 \\
(0.87)\end{array}$ & 0.695 & 0.824 & 240 \\
\hline Met Group Members Before & $\begin{array}{c}0.93 \\
(0.26)\end{array}$ & $\begin{array}{c}0.86 \\
(0.35)\end{array}$ & 0.067 & 0.067 & 252 \\
\hline Identify Ethnicity of Other Group Members & $\begin{array}{c}0.98 \\
(0.13)\end{array}$ & $\begin{array}{c}0.99 \\
(0.09)\end{array}$ & 0.562 & 0.563 & 252 \\
\hline
\end{tabular}

Note: All educations and age are in years; all professions are dummy variables where 1 equals farming and 0 otherwise; apart from Daily Income, all other incomes are monthly (in Bangladeshi Taka); Land Possession is the amount of land owned in 'katha', where 1 katha $=720$ square feet; Marriage is a dummy variable where 1 equals married (at least once) and 0 otherwise; Parents' Education and Income are accumulated education and incomes of mothers and fathers; IC Competence is the level of inter-cultural competence among Santals and Bengalis, where 0 means no knowledge about the other ethnic group, 0.25 means some knowledge, 0.5 means good knowledge, 0.75 means very good knowledge and 1 means excellent knowledge; Know Other Participant's Name shows the number of group members' names a participant knew, where 5 implies knowing everyone's name and 0 means not knowing anyone's name; Met Group Members Before indicates the proportion of individuals who have met/known their group members from before; Identifying Ethnicity of Other Group Members is a variable that shows the proportion of individuals who could identify all their group members ethnic identities correctly; MW-test is a two sided Mann-Whitney U test and T-test is a two-sample t-test with unequal variances.

a perceived rank of either 1 or 2 for his own performance in stage 2 and 0 otherwise. One's perceived probability of winning in the compulsory tournament can be a proxy 
for the probability of winning in the discretionary tournament in stage 3 , assuming no expected increase in ability from stage 2 to 3 . There are no significant differences across group compositions and ethnic groups in this measure (CS-test $p>0.10$ for all). See Table 1 in Appendix A for the summary and test results. Summary of guessed ranks is available in Table 2 in Appendix A.

Finally, Table 2 summarizes elicited risk attitudes by ethnic group. The two ethnic groups demonstrate almost identical attitude towards risk (CS-test $p=0.543) .{ }^{25} \mathrm{We}$ also control for these elicited attributes in our regression analysis.

\subsection{Performance in Stages 1 and 2}

Summary statistics of performance in stages 1 and 2 and tests of the equality of means and distributions across ethnic groups and treatments are presented in Table 3. Overall, when comparing performance across ethnic groups, there are no differences in either stage. The same is true when we make interethnic comparisons of performance for each treatment separately (Panel A of Table 3), with the exception of the majority treatment in stage 1, in which Bengali subjects perform better than Santal subjects, though the difference is marginally significant (MW-test: $p=0.054$ ). Thus, we confirm that there are no significant differences in ability to perform the task across the two ethnic groups.

We next examine whether there are across treatment differences in performance in stage 1; see Graph A in Figure 3 for a visualization of these differences for each ethnic group separately. What emerges is a similar pattern for both ethnic groups: performance is higher in the mixed (majority and minority) treatments than the homogeneous treatment, though the differences are statistically significant only for Bengalis (tests are reported in Panel B of Table 3). The fact that in mixed treatments performance is higher when compensation is not competitive is surprising.

Regarding stage 2 performance, we find a similar pattern as in stage 1 (see Figure 3; Graph B). For both ethnic groups, performance in majority and minority treatments

\footnotetext{
${ }^{25}$ Since the Risk Game was conducted as a separate 'bonus' game which took place immediately after the main game ended, participants knew they were not part of their group any longer prior to making risky investment decisions. Also, participants made their risky decisions individually and away from their group table, so group composition should not have affected their behavior. However, test results suggest otherwise. Between ethnic groups tests show that Santals, who were in a homogeneous treatment, invested significantly more than Bengalis (CS-test $p=0.011$ ); investments in other groups, however, were not significantly different between ethnicity (CS-test $p>0.10$ for all other groups). Likewise, within ethnic groups tests show that Santals from the homogeneous treatment invested significantly more than their co-ethnics in majority and minority treatment groups. Although among Bengali subjects, all investments were equal (CS-test $p>0.10$ for all).
} 
Table 2: Summary of Risky Investment

\begin{tabular}{|c|c|c|c|c|c|c|}
\hline & $\begin{array}{c}\text { Bengali } \\
(\text { Std. Dev. })\end{array}$ & $N_{B}$ & $\begin{array}{c}\text { Santal } \\
\text { (Std. Dev.) }\end{array}$ & $N_{S}$ & $\begin{array}{c}\text { MW-test } \\
p \text {-values }\end{array}$ & $\begin{array}{c}\text { CS-test } \\
p \text {-values }\end{array}$ \\
\hline Proportion Invested & $\begin{array}{c}0.85 \\
(0.23)\end{array}$ & 126 & $\begin{array}{c}0.88 \\
(0.22)\end{array}$ & 126 & 0.219 & 0.543 \\
\hline Homogeneous & $\begin{array}{c}0.81 \\
(0.26)\end{array}$ & 60 & $\begin{array}{c}0.93 \\
(0.20)\end{array}$ & 60 & 0.002 & 0.011 \\
\hline Majority & $\begin{array}{c}0.91 \\
(0.20)\end{array}$ & 44 & $\begin{array}{c}0.83 \\
(0.24)\end{array}$ & 44 & 0.095 & 0.402 \\
\hline Minority & $\begin{array}{c}0.85 \\
(0.23)\end{array}$ & 22 & $\begin{array}{c}0.85 \\
(0.24)\end{array}$ & 22 & 0.823 & 0.597 \\
\hline Mixed & $\begin{array}{c}0.89 \\
(0.21)\end{array}$ & 66 & $\begin{array}{c}0.84 \\
(0.24)\end{array}$ & 66 & 0.231 & 0.631 \\
\hline
\end{tabular}

Panel B: Compares Risky Investment Within Ethnic Groups

\begin{tabular}{llcccc}
\hline & $\begin{array}{c}\text { Group } \\
\text { Treatment }\end{array}$ & & $\begin{array}{c}\text { Group } \\
\text { Treatment }\end{array}$ & $\begin{array}{c}\text { MW-test } \\
\boldsymbol{p} \text {-values }\end{array}$ & $\begin{array}{c}\text { CS-test } \\
\boldsymbol{p} \text {-values }\end{array}$ \\
\hline \multirow{3}{*}{ Bengali } & Homogeneous & vs & Majority & 0.052 & 0.136 \\
& Homogeneous & vs & Minority & 0.749 & 0.420 \\
& Majority & vs & Minority & 0.180 & 0.253 \\
Homogeneous & vs & Mixed & 0.114 & 0.280 \\
& Homogeneous & vs & Majority & 0.006 & 0.025 \\
& Homogeneous & vs & Minority & 0.047 & 0.073 \\
& Majority & vs & Minority & 0.729 & 0.879 \\
& Homogeneous & vs & Mixed & 0.005 & 0.022 \\
\hline
\end{tabular}

Note: 'Proportion Invested' is the proportion of endowment invested in the risky lottery; Mixed group combines risky investments of both Minority and Majority group treatments; $N_{B}$ is the sample of Bengali and $N_{S}$ is the sample of Santal.

Figure 3: Performance: Comparing Performances Within Ethnic Groups
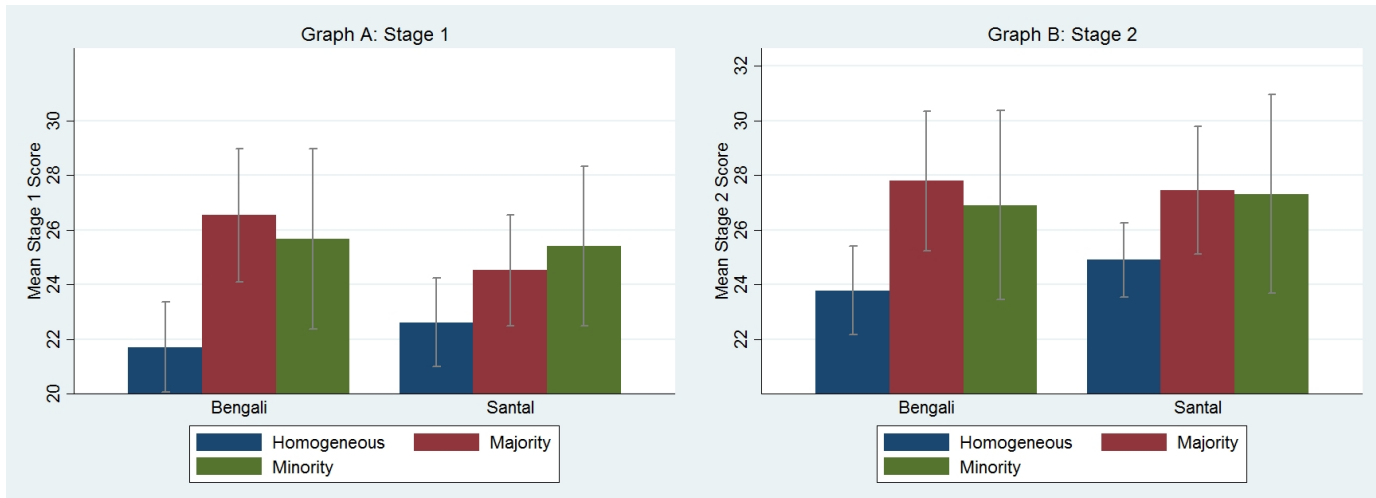

Note: Each bar represents the mean score of participants in Stages 1 and 2 with 95 percent confidence interval. 
is higher compared to the homogeneous treatment. ${ }^{26}$ Furthermore, the difference in performance between homogeneous and mixed treatments is statistically significant for both ethnic groups (though only marginal for Santals), when we pool scores from majority and minority treatments together (MW-test: $p=0.071$ for Santals and $p<0.01$ for Bengalis). ${ }^{27}$ This finding is expected in this stage with a competitive incentive structure in place, as participants may be more likely to internalize the negative externality imposed on their co-ethnic as opposed to members of the other ethnicity.

Comparing performance across stages 1 and 2, we see a significant performance improvement from stage 1 to stage 2 for both ethnic groups (Wilcoxon signed-rank test (SR-test): $p<0.01$ for both). Among Bengalis, this improvement is entirely driven by members of the homogeneous group, however, this is not the case among Santals. See Table 3 in Appendix A for the summary and test results. The increase in performance moving from piece-rate to competitive incentive is consistent with existing studies on performance and competitiveness, which show that participants, on average, perform significantly better in tournaments as compared to piece-rate schemes (Gneezy et al., 2003; Niederle \& Vesterlund, 2007; Buser et al., 2014).

In summary, we find no significant differences, overall or by treatment, in performance across the two ethnic groups. At the same time, we do see that for both groups performance is higher in ethnically-mixed as compared to homogeneous treatments, with differences being stronger for the ethnic majority group.

\subsection{Competitive Choice}

Overall, we do not find any differences in competitive choices across ethnic groups in stage 3. As shown in Table 4, an equal fraction of Santals and Bengalis (37 percent) opted to compete in the choice stage (CS-test: $p=0.896$ ), which is inconsistent with our alternative hypothesis 3 . However, when we look across treatments, we see some marked differences between the two ethnic groups. In particular, although marginal, in homogeneous treatment more Santals opted to compete (CS-test: $p=0.087$ ), whereas in minority treatment more Bengalis opted to compete (CS-test: $p=0.026)$. Considering all treatment groups, there is a completely reverse pattern in competitive choices made by the two ethnic groups, which is evident in Figure 4. We see that Santals choose to compete the most in homogeneous treatment and the least in minority treatment,

\footnotetext{
${ }^{26}$ Note that this finding suggests that fear of retaliation is not a main driver of behavior in this study, for if it were, we would expect the opposite pattern, that is Santals in mixed treatments (where arguably that fear is most serious) would perform worse than in the homogeneous treatment.

${ }^{27}$ There is no statistically significant difference in performance across the majority and the minority treatments (MW-test: $p>0.10$ for both ethnic groups).
} 
Figure 4: Competitive Choice: Comparing Choices Within Ethnic Groups

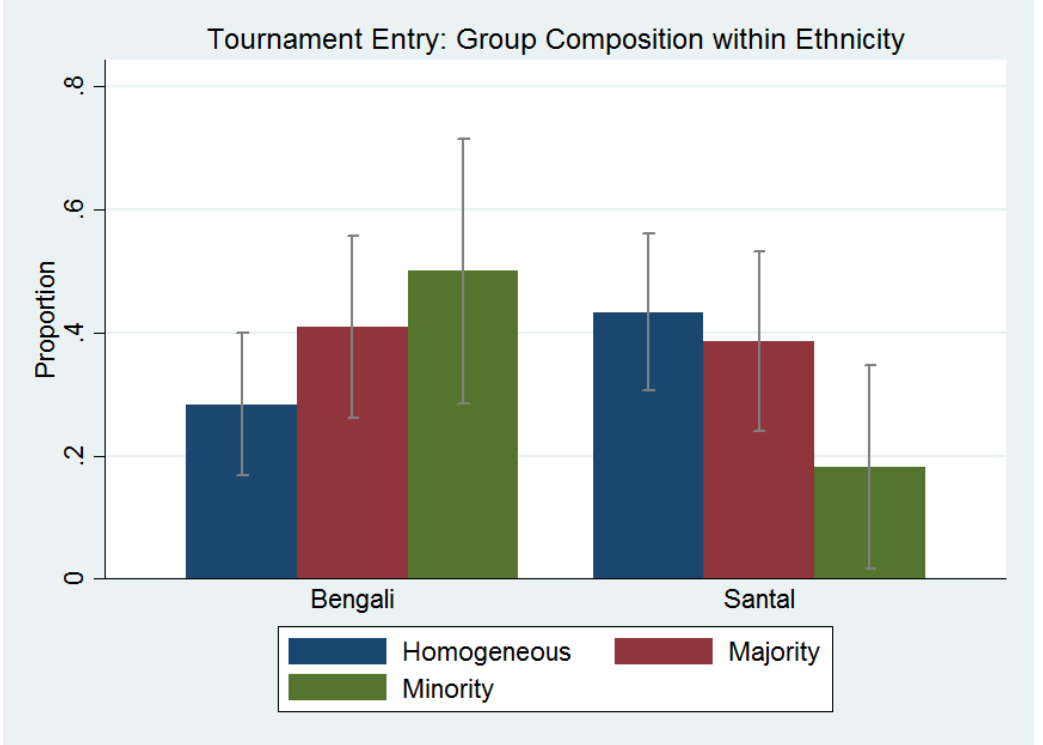

Note: Each bar represents the proportion of participants who opted to compete in stage 3 with 95 percent confidence interval. Homogeneous is a group composition where all individuals are co-ethnics; Majority is a group composition where either Santals or Bengalis are numerical majorities; Minority is a group composition where either Santals or Bengalis are numerical minorities.

whereas this relationship is reversed for Bengalis, who opted to compete the most in minority treatment and the least in homogeneous treatment. ${ }^{28}$ While half of Bengalis chose to compete in a minority treatment, only 18 percent of Santals opted to compete in that same treatment, and for both ethnic groups, these differences are statistically significant (though only marginal for Bengalis) when compared against choices made in homogeneous treatment (CS-test: $p=0.067$ for Bengalis and $p=0.036$ for Santals), which is consistent with our hypothesis 3 .

This implies that as groups get more populated by Santals, Bengalis show higher tendency to compete; on the other hand, as the number of Bengalis increases in a group, Santals are less likely to compete. It is noteworthy that for the Bengalis the pattern of entry across treatment we see in Figure 4 is consistent with performance in stage 2, namely, there is more entry in the mixed treatment that performed better in stage 2 than the homogeneous treatment. For the Santals, however, it is not, as we see more entry in the homogeneous treatment that performed the worst in stage 2 .

To probe further what drives the patterns underscored above, it is instructive to examine whether there are differences between ethnic group within treatment or within

\footnotetext{
${ }^{28}$ Tests of treatment differences for each ethnic group are presented in Panel B of Table 4.
} 


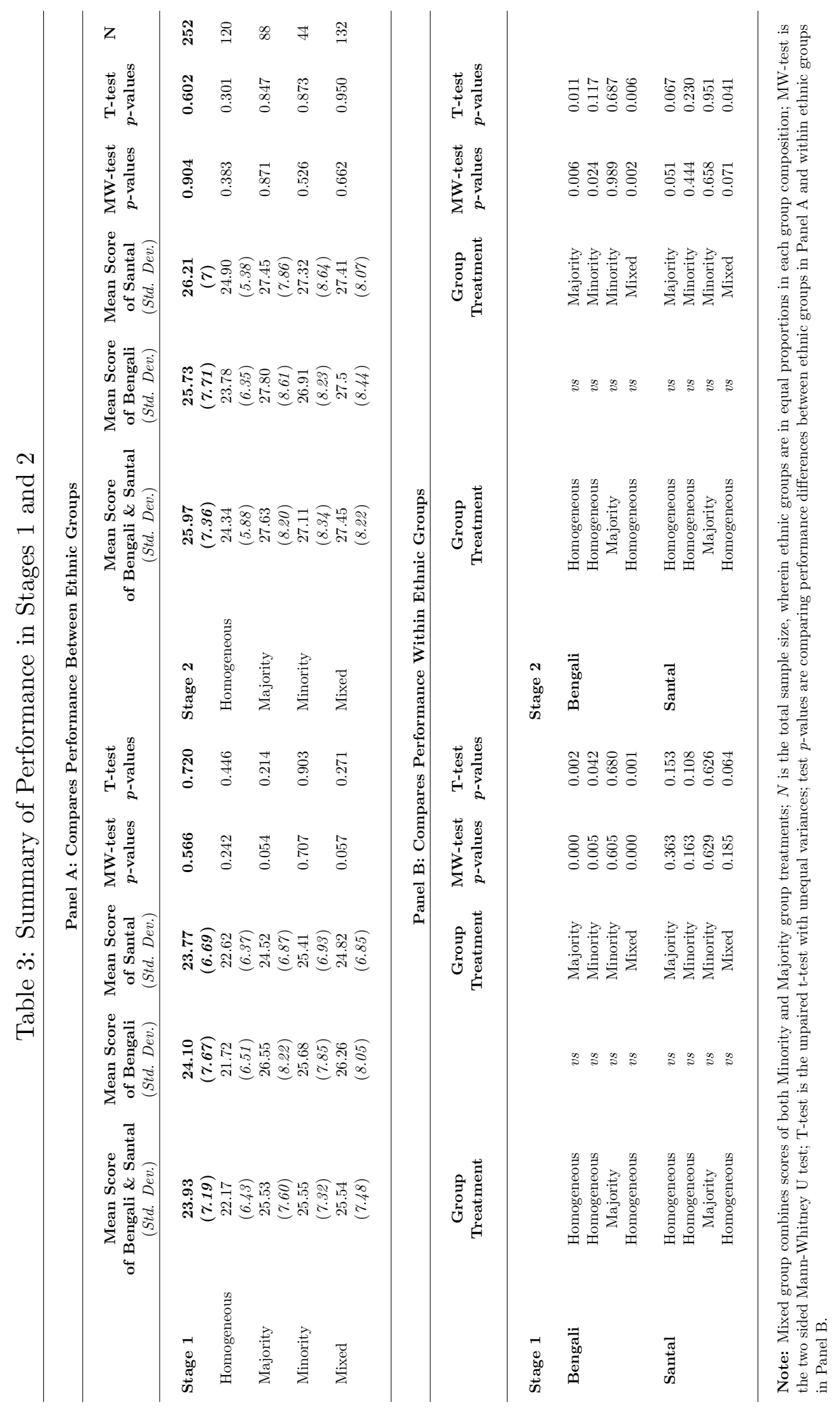


Table 4: Summary of Competitive Choice

Panel A: Compares Competitive Choice Between Ethnic Groups

\begin{tabular}{|c|c|c|c|c|c|c|}
\hline & $\begin{array}{c}\text { Proportion of } \\
\text { Bengali } \\
(S t d . \text { Dev. }) \\
\end{array}$ & $N_{B}$ & $\begin{array}{c}\text { Proportion of } \\
\text { Santal } \\
(S t d . D e v .) \\
\end{array}$ & $N_{S}$ & $\begin{array}{c}\text { MW-test } \\
p \text {-values }\end{array}$ & $\begin{array}{c}\text { CS-test } \\
p \text {-values }\end{array}$ \\
\hline Compete & $\begin{array}{c}0.37 \\
(0.48)\end{array}$ & 126 & $\begin{array}{c}0.37 \\
(0.49)\end{array}$ & 126 & 0.896 & 0.896 \\
\hline Homogeneous & $\begin{array}{c}0.28 \\
(0.45)\end{array}$ & 60 & $\begin{array}{c}0.43 \\
(0.50)\end{array}$ & 60 & 0.088 & 0.087 \\
\hline Majority & $\begin{array}{c}0.41 \\
(0.50)\end{array}$ & 44 & $\begin{array}{c}0.39 \\
(0.49)\end{array}$ & 44 & 0.829 & 0.828 \\
\hline Minority & $\begin{array}{c}0.50 \\
(0.51)\end{array}$ & 22 & $\begin{array}{c}0.18 \\
(0.39)\end{array}$ & 22 & 0.028 & 0.026 \\
\hline Mixed & $\begin{array}{c}0.44 \\
(0.50)\end{array}$ & 66 & $\begin{array}{c}0.32 \\
(0.47)\end{array}$ & 66 & 0.153 & 0.151 \\
\hline
\end{tabular}

Panel B: Compares Competitive Choice Within Ethnic Groups

\begin{tabular}{llllcc}
\hline & $\begin{array}{c}\text { Group } \\
\text { Treatment }\end{array}$ & & $\begin{array}{c}\text { Group } \\
\text { Treatment }\end{array}$ & $\begin{array}{c}\text { MW-test } \\
\boldsymbol{p} \text {-values }\end{array}$ & $\begin{array}{c}\text { CS-test } \\
\boldsymbol{p} \text {-values }\end{array}$ \\
\hline \multirow{3}{*}{ Bengali } & Homogeneous & vs & Majority & 0.182 & 0.180 \\
& Homogeneous & vs & Minority & 0.069 & 0.067 \\
& Majority & vs & Minority & 0.486 & 0.483 \\
& Homogeneous & vs & Mixed & 0.070 & 0.069 \\
& Homogeneous & vs & Majority & 0.633 & 0.631 \\
& Homogeneous & vs & Minority & 0.037 & 0.036 \\
& Majority & vs & Minority & 0.095 & 0.093 \\
& Homogeneous & vs & Mixed & 0.184 & 0.182 \\
\hline
\end{tabular}

Note: 'Compete' is a dummy variable and is equal to 1 if the individual opted to compete and 0 otherwise; Mixed group pools both Minority and Majority groups together; $N_{B}$ is the Bengali sample; $N_{S}$ is the Santal sample; test $p$-values are comparing choices horizontally.

ethnic group between treatment in the optimality of the decisions made in this stage, both for entrants and non-entrants. Following Buser et al. (2014), for each subject we compute the probability of winning the tournament conditional on stage 2 performance, by randomly drawing 1,000 different comparison groups from a participant's own group composition type, i.e. homogeneous, Santal-majority, and Santal-minority. Using the winning probabilities, we then compute the expected payoff of each participant in a tournament, conditional on their stage 2 performance, to assess the optimality of their 
tournament entry decisions. ${ }^{29}$ Summary statistics and test results are presented in Table 5.

We first examine those who under-entered the tournament. ${ }^{30}$ In Panel A, we see that there are no significant differences in under-entry between ethnic groups in any group treatments (CS-test: $p>0.10$ for all group treatments). Likewise, within ethnic group tests in Panel B also suggest that the patterns of competitive entry underlined in the previous subsection cannot be explained by across treatment differences in underentry. Now turning our attention to those who over-entered the tournament, it turns out that Bengalis over-entered significantly more than Santals in the minority treatment (Panel A; CS-test: $p=0.009$ ). Moreover, within ethnicity across treatment tests suggest that Santals over-entered significantly more in homogeneous and majority treatments than in the minority treatment (Panel B; CS-test: $p=0.029$ for both homogeneous vs. minority and majority vs. minority treatments). For Bengalis, we do not find any significant differences in over-entry across treatments.

Overall, this optimal-entry analysis indicates that there was substantial over-entry into competition across ethnic groups and treatments, apart from Santals in the minority treatment. For Santals, the difference in competitive choice between the homogeneous and the minority treatment, seen in Table 4, is driven by more over-entry in the homogeneous treatment. The reason for this could be that for Santals the tendency to over-enter into competition suboptimally is inhibited when in the minority treatment because they feel inferior. Furthermore, considering the between ethnic group comparison, we find that Bengalis over-enter significantly more than Santals in the minority treatment. This gap between ethnic groups is also consistent with Santals feeling inferior and Bengalis feeling superior when in a numerical minority group.

\subsection{Regression Analysis of Compensation Choice in Stage 3}

The foregoing analysis provides some insight on how group compositions influence inclinations towards competition. In this subsection, we further scrutinize the choice made in stage 3 in a regression framework that allows us to control for other factors that

\footnotetext{
${ }^{29}$ Entering competition is optimal when the expected payoff under the tournament is higher than the expected payoff under the piece-rate given the stage 2 performance. As entering competition and winning results in six times the piece-rate payment $(x)$ for our subjects, choosing competition is optimal for a risk neutral subject if $6 x \times \operatorname{Pr}($ Win $)>x$, or $6 \times \operatorname{Pr}($ Win $)>1$.

${ }^{30}$ Following Andersen et al. (2013), we say that under-entry occurs when it is optimal for subjects to enter competition but they do not enter. Similarly, over-entry occurs when it is not optimal for subjects to enter competition but they enter anyway. Finally, correct entry occurs when it is the optimal decision for subjects to enter/not enter the competition.
} 


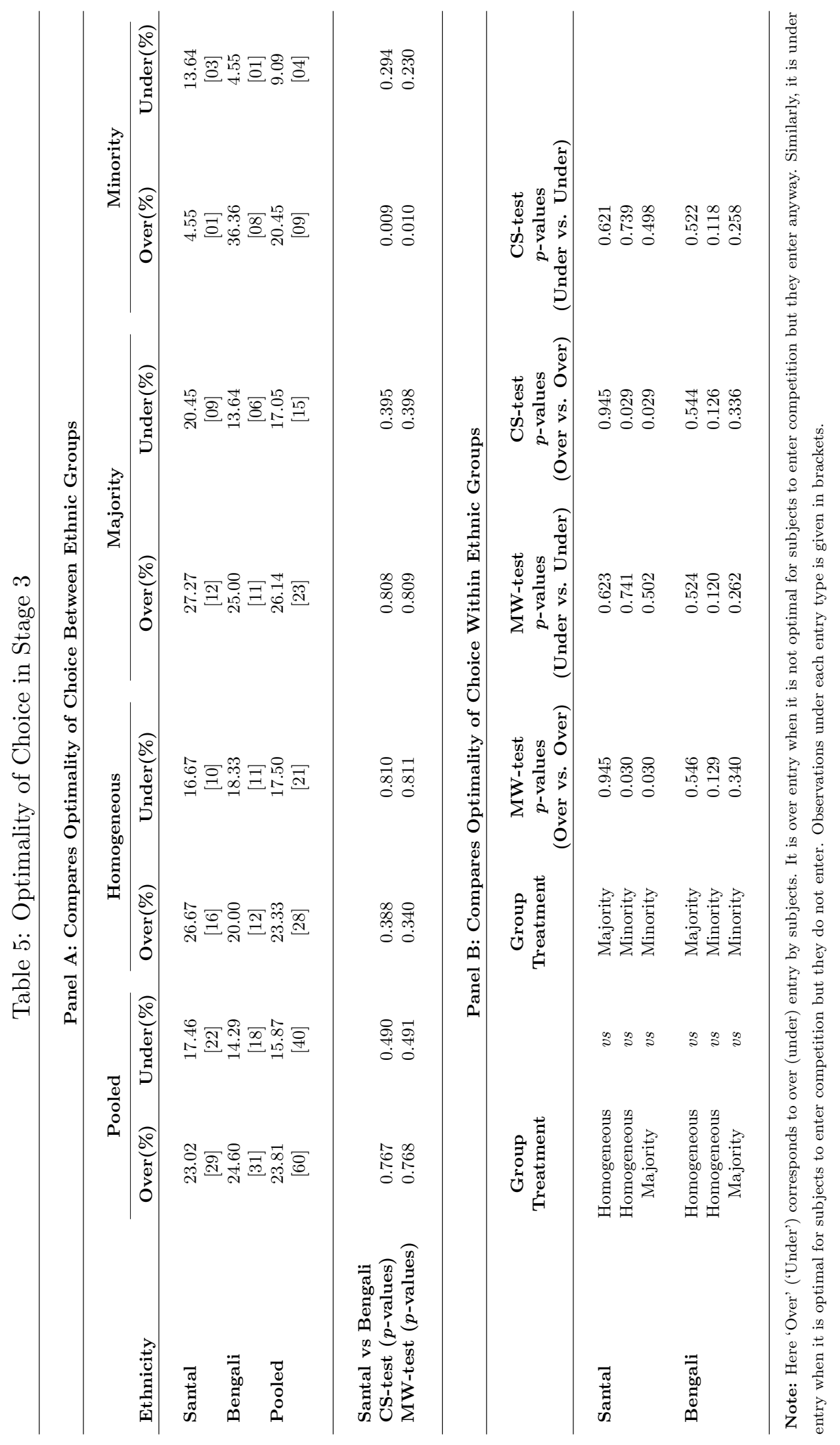


might affect a subject's tournament entry decision such as previous performance, risk preference, perceived probability of winning a tournament and various socioeconomic characteristics (age, income, education and so on). Firstly, to examine whether the two ethnic groups differ in terms of the across treatments differences in willingness to compete, we estimate the following equation:

$$
\begin{aligned}
\text { Compete }_{i} & =\alpha+\beta_{1} \text { Santal }_{i}+\beta_{2} \text { Minority }_{i}+\beta_{3} \text { Majority }_{i}+\beta_{4} \text { Santal }_{i} \times \text { Minority }_{i} \\
& +\beta_{5} \text { Santal }_{i} \times \text { Majority }_{i}+S^{\prime} \gamma+\lambda p_{i}+\sigma r_{i}+X^{\prime} \theta+\epsilon_{i}
\end{aligned}
$$

The dependent variable Compete is equal to 1 if a participant chooses to compete in stage 3 and 0 otherwise. Santal is an indicator variable for the ethnic minority. Minority and Majority are indicator variables for minority and majority treatments, respectively. $S$ is a vector of previous performances. $p$ and $r$ are perceived probability of winning and risk respectively, which are described in section 3 and summaries are given in Table 1 in Appendix A and Table 2. $X$ is a vector of all other controls, which include age, income, education, land possession, profession, the level of intercultural competence, having met other participants and the village of the participant. Standard errors are clustered at the session level. ${ }^{31}$ Columns 1-6 in Table 6 contain estimated average marginal effects from a probit regression. All results are robust to using logit and linear probability models.

Column 1 only includes the main effects of interest, and we incrementally add controls as we proceed from Column 2-6 to see whether each subsequently affects our main results. The rightmost column has the full set of controls as laid out in our probit regression equation 1 . What we see is that without any controls, the Santal $\times$ Minority interaction is statistically significant and negative, suggesting that the Santals are significantly less likely to enter competition in the minority treatment relative to the homogeneous treatment than the Bengalis (a difference-in-difference of almost 34 percentage points), while Santals in the minority treatment are 20 percentage points less likely to enter competition than the Bengalis in the same treatment. As we add to the specification previous performances, perceived probability of winning a tournament and attitudes towards risk in Columns 2-4, respectively, we observe a small reduction in the size of the marginal effect which remains though large and negative. ${ }^{32}$ When we further add back-

\footnotetext{
${ }^{31}$ Clustering standard errors at the group and at the village of participants level yields very similar results.

${ }^{32}$ Our results are robust to using guessed rank (see Table 2 in Appendix A for summary statistics)
} 
Table 6: Treatment Effects on Willingness to Compete: Ethnic Group Differences

\begin{tabular}{|c|c|c|c|c|c|c|}
\hline VARIABLES & $(1)$ & $(2)$ & $(3)$ & $(4)$ & $(5)$ & $(6)$ \\
\hline Santal & $\begin{array}{c}0.146 \\
(0.110)\end{array}$ & $\begin{array}{c}0.127 \\
(0.107)\end{array}$ & $\begin{array}{c}0.131 \\
(0.108)\end{array}$ & $\begin{array}{c}0.089 \\
(0.109)\end{array}$ & $\begin{array}{l}-0.008 \\
(0.138)\end{array}$ & $\begin{array}{c}0.005 \\
(0.124)\end{array}$ \\
\hline Minority & $\begin{array}{c}0.212 \\
(0.153)\end{array}$ & $\begin{array}{c}0.150 \\
(0.175)\end{array}$ & $\begin{array}{c}0.163 \\
(0.171)\end{array}$ & $\begin{array}{c}0.149 \\
(0.166)\end{array}$ & $\begin{array}{c}0.084 \\
(0.177)\end{array}$ & $\begin{array}{c}0.038 \\
(0.161)\end{array}$ \\
\hline Majority & $\begin{array}{c}0.127 \\
(0.133)\end{array}$ & $\begin{array}{c}0.047 \\
(0.156)\end{array}$ & $\begin{array}{c}0.066 \\
(0.154)\end{array}$ & $\begin{array}{c}0.026 \\
(0.148)\end{array}$ & $\begin{array}{c}0.006 \\
(0.153)\end{array}$ & $\begin{array}{l}-0.022 \\
(0.155)\end{array}$ \\
\hline Santal $\times$ Minority & $\begin{array}{c}-0.343^{* * *} \\
(0.053)\end{array}$ & $\begin{array}{c}-0.338^{* * *} \\
(0.057)\end{array}$ & $\begin{array}{c}-0.337^{* * *} \\
(0.057)\end{array}$ & $\begin{array}{c}-0.318^{* * *} \\
(0.066)\end{array}$ & $\begin{array}{c}-0.308^{* * *} \\
(0.066)\end{array}$ & $\begin{array}{c}-0.309^{* * *} \\
(0.063)\end{array}$ \\
\hline Santal $\times$ Majority & $\begin{array}{l}-0.157 \\
(0.157)\end{array}$ & $\begin{array}{l}-0.125 \\
(0.169)\end{array}$ & $\begin{array}{c}-0.132 \\
(0.168)\end{array}$ & $\begin{array}{c}-0.060 \\
(0.178)\end{array}$ & $\begin{array}{l}-0.088 \\
(0.168)\end{array}$ & $\begin{array}{l}-0.145 \\
(0.152)\end{array}$ \\
\hline Stage 1 Score & - & $\begin{array}{c}0.003 \\
(0.008)\end{array}$ & $\begin{array}{c}0.002 \\
(0.008)\end{array}$ & $\begin{array}{c}0.002 \\
(0.008)\end{array}$ & $\begin{array}{c}0.003 \\
(0.008)\end{array}$ & $\begin{array}{c}0.002 \\
(0.008)\end{array}$ \\
\hline Stage 2 Score & - & $\begin{array}{c}0.014^{* * *} \\
(0.005)\end{array}$ & $\begin{array}{c}0.013^{* *} \\
(0.006)\end{array}$ & $\begin{array}{c}0.012^{* *} \\
(0.006)\end{array}$ & $\begin{array}{l}0.012^{*} \\
(0.006)\end{array}$ & $\begin{array}{c}0.009 \\
(0.006)\end{array}$ \\
\hline Perceived Probability of Winning & - & - & $\begin{array}{c}0.075 \\
(0.058)\end{array}$ & $\begin{array}{c}0.053 \\
(0.061)\end{array}$ & $\begin{array}{c}0.064 \\
(0.069)\end{array}$ & $\begin{array}{c}0.049 \\
(0.068)\end{array}$ \\
\hline Risk & - & - & - & $\begin{array}{c}0.004^{* *} \\
(0.002)\end{array}$ & $\begin{array}{c}0.004^{* *} \\
(0.002)\end{array}$ & $\begin{array}{c}0.003^{* *} \\
(0.001)\end{array}$ \\
\hline IC Competence & - & - & - & - & $\begin{array}{c}0.286^{*} \\
(0.149)\end{array}$ & $\begin{array}{l}0.290^{*} \\
(0.153)\end{array}$ \\
\hline Daily Income & - & - & - & - & $\begin{array}{c}0.000^{* * *} \\
(0.000)\end{array}$ & $\begin{array}{c}0.000^{* *} \\
(0.000)\end{array}$ \\
\hline Profession & - & - & - & - & $\begin{array}{c}-0.004 \\
(0.060)\end{array}$ & $\begin{array}{c}0.010 \\
(0.037)\end{array}$ \\
\hline Land Possession & - & - & - & - & $\begin{array}{l}-0.001 \\
(0.001)\end{array}$ & $\begin{array}{l}-0.001 \\
(0.001)\end{array}$ \\
\hline Other Controls & No & No & No & No & No & Yes \\
\hline Village Fixed Effects & No & No & No & No & No & Yes \\
\hline Observations & 252 & 252 & 252 & 252 & 250 & 250 \\
\hline Pseudo $R^{2}$ & 0.026 & 0.073 & 0.077 & 0.103 & 0.128 & 0.213 \\
\hline
\end{tabular}

Note: Probit regressions with average marginal effects reported; dependent variable is "compete", which equals 1 when the individual opted to compete and 0 otherwise; two observations were dropped in Column 5 and 6 because a Santal and a Bengali in a homogeneous treatment did not provide their income level; 'Other Controls' include age, education and having met other group members before. Table 1 describes all control variables.

ground characteristics such as daily income, profession, land possession and knowledge regarding other culture as controls (Column 5) as well as other controls (Column 6), our

or the difference between actual and guessed rank (a measure of overconfidence used in Niederle \& Vesterlund (2007) and other subsequent studies) as a measure of beliefs about relative ability instead of the perceived probability of winning. Also, controlling for the average score of adjacent peers (those seated next to, in front of and in the adjacent corner of a subject a well as all peers in the group) in stage 2 does not affect the results. 
main marginal effects of interest remain robustly negative and sizeable. ${ }^{33}$ With a full set of controls, in Column (6), the difference in competitive inclination between Santals in a minority treatment and a homogeneous treatment is 30.9 percentage points less than the difference in competitive inclination between Bengali in a minority treatment and a homogeneous treatment. Note that this difference-in-difference is fully accounted by the across ethnic group difference in the minority treatment as the across ethnic group difference in the homogeneous treatment has been reduced almost to zero. Hence, with regard to ethnic differences, our regression results are consistent with our third hypothesis. ${ }^{34}$

Next, to obtain a clear picture of the size of the group composition effects, we estimate another probit regression model for each ethnic group separately. Table 7 shows our estimated results: Columns S1-S3 for Santals and Columns B1-B3 for Bengalis. As expected, we observe heterogeneous effects of group composition across the two ethnic groups. Results for the Santal subsample, presented in Columns S1-S3, suggest that Santals in both minority and majority treatments are less likely to enter competition than if they are in the homogeneous treatment. The size of the estimated differences increase in size and statistical significance as we add controls in Columns S2 and S3, such that, with a full set of controls, we find that Santals in the minority treatment are 41.3 percentage points less likely to compete than Santals in the homogeneous treatment. Likewise, Santals in the majority treatment are 29.9 percentage points less likely to compete than Santals in homogeneous treatment. Of the rest of the controls, intercultural knowledge seems to be the only one to have substantial explanatory power over competitive entry.

Results for the Bengali subsample, presented in Columns B1-B3, imply a reverse relationship as depicted in Figure 4. Bengalis are more likely to compete in minority and majority treatments than their co-ethnics in the homogeneous treatment; however, the difference is not statistically significant, and it reduces in size as we add controls in Columns B2-B3. Further, it seems, for Bengalis, income and risk preferences explain almost all their tournament entry decisions. Other factors, including overconfidence and intercultural knowledge factors, fail to explain tournament entry decisions by the ethnic

\footnotetext{
${ }^{33}$ When we also add stage 3 performance as a control, with a full set of controls, it has no significant effect on choosing to compete $(p=0.895)$ and leaves the average marginal effects of minority treatments and all other effects unchanged. This suggests, the anticipation of performing better/worse did not affect tournament entry decisions. Also, instead of village dummies, using percentage of Santal population (or household) for each village of participants yields very similar results.

${ }^{34}$ Note that in groups where Bengalis are a numerical majority and Santals are a numerical minority, $41 \%$ Bengalis and $18 \%$ Santals opted to compete, and this difference is marginally significant (CS-test: $p=0.065)$. A probit regression that accounts for the controls included in Table 6 shows that this difference is robust in size and statistically significant.
} 
Table 7: Within Ethnic Group Treatment Effects on Willingness to Compete

\begin{tabular}{|c|c|c|c|c|c|c|}
\hline \multirow[b]{2}{*}{ VARIABLES } & \multicolumn{3}{|c|}{ Santal } & \multicolumn{3}{|c|}{ Bengali } \\
\hline & $(\mathrm{S} 1)$ & $(\mathrm{S} 2)$ & (S3) & (B1) & (B2) & (B3) \\
\hline Santal-Majority & $\begin{array}{c}-0.047 \\
(0.142)\end{array}$ & $\begin{array}{l}-0.159 \\
(0.124)\end{array}$ & $\begin{array}{c}-0.299^{* * *} \\
(0.105)\end{array}$ & - & - & - \\
\hline Santal-Minority & $\begin{array}{c}-0.252^{* *} \\
(0.112)\end{array}$ & $\begin{array}{c}-0.339^{* * *} \\
(0.086)\end{array}$ & $\begin{array}{c}-0.413^{* * *} \\
(0.093)\end{array}$ & - & - & - \\
\hline Bengali-Majority & - & - & - & $\begin{array}{c}0.126 \\
(0.131)\end{array}$ & $\begin{array}{l}-0.011 \\
(0.125)\end{array}$ & $\begin{array}{c}0.006 \\
(0.180)\end{array}$ \\
\hline Bengali-Minority & - & - & - & $\begin{array}{c}0.217 \\
(0.158)\end{array}$ & $\begin{array}{c}0.119 \\
(0.173)\end{array}$ & $\begin{array}{c}0.108 \\
(0.223)\end{array}$ \\
\hline Stage 1 Score & - & $\begin{array}{l}-0.004 \\
(0.013)\end{array}$ & $\begin{array}{l}-0.003 \\
(0.015)\end{array}$ & - & $\begin{array}{c}0.010 \\
(0.009)\end{array}$ & $\begin{array}{c}0.011 \\
(0.010)\end{array}$ \\
\hline Stage 2 Score & - & $\begin{array}{c}0.016^{* *} \\
(0.008)\end{array}$ & $\begin{array}{c}0.012 \\
(0.009)\end{array}$ & - & $\begin{array}{c}0.004 \\
(0.011)\end{array}$ & $\begin{array}{c}0.002 \\
(0.012)\end{array}$ \\
\hline Perceived Probability of Winning & - & $\begin{array}{c}0.105 \\
(0.099)\end{array}$ & $\begin{array}{c}0.121 \\
(0.080)\end{array}$ & - & $\begin{array}{c}-0.008 \\
(0.092)\end{array}$ & $\begin{array}{c}-0.005 \\
(0.096)\end{array}$ \\
\hline Risk & - & $\begin{array}{c}0.002 \\
(0.002)\end{array}$ & $\begin{array}{c}0.002 \\
(0.001)\end{array}$ & - & $\begin{array}{c}0.006^{* * *} \\
(0.002)\end{array}$ & $\begin{array}{c}0.006^{* * *} \\
(0.002)\end{array}$ \\
\hline IC Competence & - & $\begin{array}{c}0.632^{* * *} \\
(0.235)\end{array}$ & $\begin{array}{c}0.647^{* * *} \\
(0.156)\end{array}$ & - & $\begin{array}{c}0.075 \\
(0.192)\end{array}$ & $\begin{array}{c}0.081 \\
(0.184)\end{array}$ \\
\hline Daily Income & - & - & $\begin{array}{c}0.000 \\
(0.001)\end{array}$ & - & - & $\begin{array}{c}0.000^{* *} \\
(0.000)\end{array}$ \\
\hline Profession & - & - & $\begin{array}{l}-0.005 \\
(0.044)\end{array}$ & - & - & $\begin{array}{c}0.034 \\
(0.068)\end{array}$ \\
\hline Land Possession & - & - & $\begin{array}{l}-0.001 \\
(0.001)\end{array}$ & - & - & $\begin{array}{c}-0.001 \\
(0.001)\end{array}$ \\
\hline Other Controls & No & No & Yes & No & No & Yes \\
\hline Village Fixed Effects & No & No & Yes & No & No & Yes \\
\hline Observations & 126 & 126 & 125 & 126 & 126 & 123 \\
\hline Pseudo $R^{2}$ & 0.029 & 0.139 & 0.314 & 0.023 & 0.141 & 0.190 \\
\hline
\end{tabular}

Note: Probit regressions with average marginal effects reported; dependent variable is "compete", which equals 1 when the individual opted to compete and 0 otherwise; the omitted group for Santals (specifications S1-S3) is the Santal homogeneous, and that of Bengalis (specifications B1-B3) is the Bengali homogeneous; two observations were dropped in Columns S3 and B3 because a Santal and a Bengali in a homogeneous group refused to provide their income level. Also two villages were dropped in the Bengali data due to having single observations in each village; 'Other Controls' include age, education and having met other group members before. Table 1 describes all control variables.

majority members. 


\subsection{Understanding the Mechanism}

As highlighted in Section 2, the two ethnic groups that we study differ markedly in terms of their socio-economic situation. This is also true in our subject pool: Bengali participants are wealthier (in terms of land ownership) and have higher earnings than their Santal counterparts (see Table 1). In this subsection, we examine to what extent the ethnic differences in preferences for interethnic competition that we find are mediated through ethnic differences in income or social status. To this end, we exploit the fact that we have measures of participants' income and land ownership, which we believe, given the degree of familiarity among the participants, can also be estimated by one's opponents in the group. We do not, however, have individual measures of social status and power, though, it is quite plausible that income/wealth and social status are correlated in this context. Therefore, if controlling for material resources, such as income and land ownership, of the group of competitors eliminates the main treatment effects that we find above, then this would provide support for the notion that preferences for interethnic competition amongst our subjects are driven mainly by ethnic differences in material well-being (and social status to the extent that they are correlated). However, if there remains a significant treatment effect, then this would indicate that it is mainly differences in unmeasured dimensions, e.g. social power and status, marked by ethnic identity, that are important for understanding the different attitudes toward interethnic competition.

Table 8 contains regression estimates of specification 1 , in which in addition to the full set of controls used in column 6 of Table 6 we are also controlling for the average daily income and/or land possession of one's group of competitors. We also present estimates where we use the number of competitors in the group who are among the top $25 \%$ earners/wealthiest, as an alternative measure of the opponents' wealth. ${ }^{35} \mathrm{We}$ see that while opponents' measures of income and wealth are negatively associated with competitive entry, the pattern of within treatment ethnic differences in competitive entry are similar and statistically indistinguishable from the ones reported above in Table 6, that is, Santals in the minority treatment are around 30 percentage points less likely to enter competition than Bengalis in the same treatment. ${ }^{36}$ We also estimated within ethnic group treatment differences adding measures of the opponents' wealth as controls,

\footnotetext{
${ }^{35}$ Top $25 \%$ earners are those that earn more than 200 Taka per day or own more than 5 kathas of land (those who are in the top quartile only).

${ }^{36}$ We perform a number of unreported additional separate robustness checks: we control for the maximum income and wealth of competitors, the number of top $10 \%$ earners/wealthiest competitors in a group and the number of top earners/wealthiest opponents nonlinearly. We find that our main results remain robust throughout.
} 
Table 8: Treatment Effects on Willingness to Compete: Ethnic Group Differences with Material Well-Beings of Competitors as Controls

\begin{tabular}{|c|c|c|c|c|c|c|}
\hline \multirow[b]{2}{*}{ VARIABLES } & \multicolumn{3}{|c|}{ Averages of Competitors } & \multicolumn{3}{|c|}{ Number of Top $25 \%$} \\
\hline & (Income) & (Land) & (Both) & (Income) & (Land) & (Both) \\
\hline Santal & $\begin{array}{l}-0.021 \\
(0.110)\end{array}$ & $\begin{array}{c}0.002 \\
(0.115)\end{array}$ & $\begin{array}{l}-0.021 \\
(0.106)\end{array}$ & $\begin{array}{l}-0.013 \\
(0.112)\end{array}$ & $\begin{array}{l}-0.014 \\
(0.111)\end{array}$ & $\begin{array}{l}-0.023 \\
(0.106)\end{array}$ \\
\hline Minority & $\begin{array}{c}0.035 \\
(0.160)\end{array}$ & $\begin{array}{c}0.012 \\
(0.161)\end{array}$ & $\begin{array}{c}0.023 \\
(0.164)\end{array}$ & $\begin{array}{c}0.009 \\
(0.146)\end{array}$ & $\begin{array}{l}-0.009 \\
(0.176)\end{array}$ & $\begin{array}{l}-0.021 \\
(0.169)\end{array}$ \\
\hline Majority & $\begin{array}{l}-0.008 \\
(0.153)\end{array}$ & $\begin{array}{l}-0.033 \\
(0.159)\end{array}$ & $\begin{array}{l}-0.014 \\
(0.157)\end{array}$ & $\begin{array}{l}-0.043 \\
(0.157)\end{array}$ & $\begin{array}{l}-0.038 \\
(0.165)\end{array}$ & $\begin{array}{l}-0.050 \\
(0.164)\end{array}$ \\
\hline Santal $\times$ Minority & $\begin{array}{c}-0.280 * * * \\
(0.068)\end{array}$ & $\begin{array}{c}-0.304^{* * *} \\
(0.062)\end{array}$ & $\begin{array}{c}-0.279^{* * *} \\
(0.067)\end{array}$ & $\begin{array}{c}-0.290 * * * \\
(0.062)\end{array}$ & $\begin{array}{c}-0.290^{* * *} * \\
(0.068)\end{array}$ & $\begin{array}{c}-0.278^{* * *} \\
(0.067)\end{array}$ \\
\hline Santal $\times$ Majority & $\begin{array}{l}-0.103 \\
(0.149)\end{array}$ & $\begin{array}{l}-0.148 \\
(0.150)\end{array}$ & $\begin{array}{l}-0.107 \\
(0.147)\end{array}$ & $\begin{array}{l}-0.116 \\
(0.160)\end{array}$ & $\begin{array}{l}-0.148 \\
(0.147)\end{array}$ & $\begin{array}{l}-0.127 \\
(0.151)\end{array}$ \\
\hline Average Income of Competitors & $\begin{array}{c}-0.001^{* * *} \\
(0.000)\end{array}$ & - & $\begin{array}{c}-0.001^{* * *} \\
(0.000)\end{array}$ & - & - & - \\
\hline Average Land of Competitors & - & $\begin{array}{l}-0.002 \\
(0.002)\end{array}$ & $\begin{array}{l}-0.001 \\
(0.002)\end{array}$ & - & - & - \\
\hline No. of Top $25 \%$ Income & - & - & - & $\begin{array}{l}-0.025 \\
(0.027)\end{array}$ & - & $\begin{array}{l}-0.017 \\
(0.025)\end{array}$ \\
\hline No. of Top $25 \%$ Land & - & - & - & - & $\begin{array}{l}-0.033 \\
(0.042)\end{array}$ & $\begin{array}{l}-0.027 \\
(0.043)\end{array}$ \\
\hline Other Controls & Yes & Yes & Yes & Yes & Yes & Yes \\
\hline Village Fixed Effects & Yes & Yes & Yes & Yes & Yes & Yes \\
\hline Observations & 250 & 250 & 250 & 250 & 250 & 250 \\
\hline Pseudo $R^{2}$ & 0.225 & 0.215 & 0.226 & 0.216 & 0.217 & 0.218 \\
\hline
\end{tabular}

Robust standard errors clustered by sessions are in parentheses

$* * * \mathrm{p}<0.01,{ }^{*} * \mathrm{p}<0.05, * \mathrm{p}<0.1$

Note: Probit regressions with average marginal effects reported; dependent variable is "compete", which equals 1 when the individual opted to compete and 0 otherwise; 'Average Income (Land) of Competitors' is the average daily income (land possession) of all five group competitors; 'No. of Top $25 \%$ Income (Land)' is the number of competitors in a group whose income (land possession) is in the top $25 \%$ among all participants; 'Other Controls' include stages 1 and 2 scores, the perceived probability of winning, risk aversion, intercultural competence, income, profession, land possession, age, education, and having met other group members before. Table 1 describes all 'Other Controls'.

separately for the two ethnic groups (see Table 4 in Appendix A); results are again similar to those reported above in Table $7 .{ }^{37}$

\footnotetext{
${ }^{37}$ We also checked whether for Santals, the effect of being grouped with more wealthy individuals (as measured by income and land possession) changes with whether they are in a minority treatment group or a majority treatment group relative to a homogeneous treatment group and do not find a significant difference. In addition, we examined whether the wealth of opponents affects Santals' competitive choice differently when the opponents are Bengali, and we did not find any substantial differences in the effect of the wealth of Santal and Bengali competitors. Finally, we also explored whether Santal characteristics, such as income, land possession, education, and age, predict Santals' competition choices in the minority and the majority treatments. We did not find robust evidence of heterogeneous treatment effects along the characteristics we examined. All of these results are available upon request.
} 
This analysis suggests that since observed differences in wealth/income of opponents do not explain differences in preferences for interethnic competition, it must be ethnic differences in dimensions unobserved to the experimenters (but evident to participants), such as social power and status, that underpin these patterns.

To further our understanding of the mechanism, we also explore whether participants with different degrees of interethnic interaction exhibit different patterns of behavior. We explore this through the measure of intercultural competence (IC), by splitting the sample of Santals and Bengalis into individuals with high intercultural competence (above median) and low intercultural competence (below median). ${ }^{38}$ Summary of the IC scores by level, ethnicity and treatment is presented in Table 5 in Appendix A. What emerges is that knowing more about the other culture is associated with higher willingness to compete across the total sample (Panel A) as well as in mixed treatment groups (Panel B). In homogeneous treatments, this is only true for Santals.

Then using a regression framework, we check whether within each ethnicity participants with a better intercultural knowledge indeed prefer to compete more or less in a mixed treatment (minority or majority) relative to the homogeneous treatment, while also accounting for the various controls (Table 9). These results suggest that the pattern we saw for the whole sample holds for both these subsamples as well, that is, Santals are less likely to enter competition when in a mixed treatment and this is true for both high and low IC participants but the treatment differences in competitive entry are smaller in the high IC group ( 7 percentage points) than the low IC group (52.5 percentage points). The interaction term indicates that for Santals the treatment differences in competitive entry is significantly different across the groups, that is, high IC is associated with a significant narrowing of competitive gap between mixed and homogeneous treatment groups.

\section{Conclusion}

This paper extends the literature on competitive preferences by exploring whether there are differences in competitive choices across members of the dominant and of a vulnerable ethnic minority group in rural Bangladesh. By varying the ethnic composition of the group of competitors, we find that members of the ethnic minority group are more averse to competing in mixed-ethnicity groups than in groups of co-ethnics. We find the

\footnotetext{
${ }^{38}$ Our intercultural competence score is very skewed for the Santal sample where $99 \%$ of Santals scored 0.50 or above and $73 \%$ scored 1 . Note that the median score for Santals and Bengalis is different in this case ( 1 and 0.50 respectively). Also, there are very few observations of Santals with below median IC score in the minority treatment, which is why we combine the two mixed treatments together.
} 
Table 9: Do more culturally competent individuals behave differently?

\begin{tabular}{lccccc}
\hline & \multicolumn{2}{c}{ Santal } & & \multicolumn{2}{c}{ Bengali } \\
\cline { 2 - 3 } \cline { 5 - 6 } VARIABLES & $\mathbf{( 1 )}$ & $\mathbf{( 2 )}$ & & $\mathbf{( 3 )}$ & $\mathbf{( 4 )}$ \\
\hline \multirow{2}{*}{ Mixed } & $-0.517^{* * *}$ & $-0.525^{* * *}$ & & -0.013 & -0.139 \\
& $(0.071)$ & $(0.067)$ & & $(0.178)$ & $(0.190)$ \\
Above Median IC & $0.244^{* *}$ & $0.219^{* *}$ & & 0.059 & 0.043 \\
& $(0.115)$ & $(0.100)$ & & $(0.158)$ & $(0.168)$ \\
Mixed $\times$ Above Median IC & $0.445^{* * *}$ & $0.456^{* * *}$ & & 0.238 & 0.244 \\
All Other Controls & $(0.076)$ & $(0.079)$ & & $(0.232)$ & $(0.231)$ \\
Village Fixed Effects & No & Yes & & No & Yes \\
Observations & No & Yes & & No & No \\
\hline
\end{tabular}

Robust standard errors clustered by sessions are in parentheses

$$
* * * \mathrm{p}<0.01,{ }^{* *} \mathrm{p}<0.05,{ }^{*} \mathrm{p}<0.1
$$

Note: Probit regressions with average marginal effects reported; dependent variable is "compete", which equals 1 when the individual opted to compete and 0 otherwise; 'Mixed' is a dummy which equals to 1 when participants are in a mixed treatment group (i.e. majority or minority) and 0 otherwise; 'Above Median IC' is a dummy if the intercultural competence score is above the median score and 0 otherwise; 'All Other Controls' include stage 1 and 2 performances, perceived probability of winning, risk, daily income, profession, land possession, age, education and having met other group members before. Table 1 describes all control variables.

opposite pattern for members of the ethnic majority group, that is, they are more keen to compete in ethnically mixed groups than in homogeneous ones. These results are consistent with competitive preferences not being a stable trait, but rather them being specific to the identity of competitors.

How important quantitatively are the ethnic differences in competitiveness that we find? After accounting for the influence of past performance, beliefs about relative performance, risk attitudes and socioeconomic characteristics, our regression analysis indicates that Santals in the minority treatment are 31 percentage points less likely to enter competition than the Bengalis in the same treatment, while Santals in the minority treatment are 41 percentage points less likely to enter competition than Santals in the homogeneous treatment. For comparison, the estimated gender gap is typically found to be about 30 percentage points (Niederle \& Vesterlund, 2007), so the quantitative effect found here would appear to be of the same or greater magnitude than the gender gap. 
The aversion to interethnic competition by the ethnic minority group may have its roots in the self-perception of the value of the ethnic identity of the particular group and the associated stereotypes that it evokes. Since, historically, one ethnic group has oppressed the other and the two have rarely coexisted peacefully, we might expect that the two ethnic groups have developed different identities and stereotypes. Assigning ethnic minority members into a group dominated by ethnic majority members might invoke the stereotype of being ethnically inferior, which might discourage them from choosing to compete. Likewise, assigning ethnic majority members into an ethnic minority dominated domain might invoke the stereotype of being ethnically superior, which might encourage them to compete more often than when being in a group of co-ethnics.

In our setting, high social power/status and minority status do not coincide. Future research could look into contexts in which the relationship between power and minority status is aligned, as is the case for instance with the Chinese population in Malaysia. One might expect that the minority groups in those contexts might have a higher propensity to compete against members of the ethnic majority group because of the enhanced power they hold. Replication of this study in such contexts would shed more light on the mechanism behind preferences for interethnic competition.

Although more evidence of the differences in preferences for interethnic competition is needed, a few pointers for policy stem from the findings we have. While policies to improve workplace diversity would be a good starting point, policy makers could also target improving competitiveness of members of minority groups through education and awareness. Educating minority members regarding self-worth, self-esteem and selfimportance, and increasing public awareness to break negative stereotypes associated with minority members might improve their competitive attitude towards the dominant group. Similarly, fostering interethnic interaction might also improve competitive attitudes of ethnic minorities. These possibilities remain interesting avenues for future research.

\section{References}

Afridi, F., Li, S. X., \& Ren, Y. (2015). Social Identity and Inequality: The Impact of China's Hukou System. Journal of Public Economics, 123, 17-29.

Ahmed, K. (2010). Defining 'Indigenous' in Bangladesh: International Law in Domestic Context. International Journal on Minority and Group Rights, 17(1), 47-73. 
AIPP (2007). A Brief Account of Human Rights Situation of the Indigenous Peoples in Bangladesh. Asian Indigenous Peoples Pact Report.

AIPP (2010). Traditional Livelihoods and Indigenous Peoples. Asia Indigenous Peoples Pact Foundation, Chiang Mai, Thailand.

Akerlof, G. A. \& Kranton, R. E. (2000). Economics and Identity. Quarterly Journal of Economics, 115(3), 715-753.

Ali, A. (1998). Santals of Bangladesh. Institute of Social Research \& Applied Anthropology, West Bengal.

Andersen, S., Ertac, S., Gneezy, U., List, J. A., \& Maximiano, S. (2013). Gender, Competitiveness, and Socialization at a Young Age: Evidence from a Matrilineal and a Patriarchal Society. The Review of Economics and Statistics, 95(4), 1438-1443.

Bal, E. (2007). 'They Ask If We Eat Frogs': Garo Ethnicity in Bangladesh. Institute of Southeast Asian Studies, Singapore.

Bandiera, O., Barankay, I., \& Rasul, I. (2005). Social Preferences and the Response to Incentives: Evidence from Personnel Data. Quarterly Journal of Economics, 120(3), 917-962.

Barndt, J. R. (2007). Understanding and Dismantling Racism. Fortress Press.

Benjamin, D. J., Choi, J. J., \& Strickland, A. J. (2010). Social Identity and Preferences. American Economic Review, 100(4), 1913-28.

Berge, L. I. O., Bjorvatn, K., Pires, A. J. G., \& Tungodden, B. (2015). Competitive in the 1Lb, Successful in the Field? Journal of Economic Behavior \&5 Organization, 118, 303-317.

Bhengra, R., Bijoy, C. R., \& Luithui, S. (1999). The Adivasis of India. Minority Rights Group International.

Booth, A., Fan, E., Meng, X., \& Zhang, D. (2019). Gender Differences in Willingness to Compete: The Role of Culture and Institutions. Economic Journal, 129(618), $734-764$.

Booth, A. \& Nolen, P. (2012). Choosing to Compete: How Different are Girls and Boys? Journal of Economic Behavior \& Organization, 81(2), 542-555. 
Bowles, S. (1998). Endogenous Preferences: The Cultural Consequences of Markets and Other Economic Institutions. Journal of Economic Literature, 36(1), 75-111.

Brauer, M. \& Bourhis, R. Y. (2006). Social Power. European Journal of Social Psychology, 36(4), 601-616.

Burow, N., Beblo, M., Beninger, D., \& Schröder, M. (2017). Why Do Women Favor Same-Gender Competition? Evidence from a Choice Experiment. DIW Berlin Discussion Paper.

Buser, T., Niederle, M., \& Oosterbeek, H. (2014). Gender, Competitiveness and Career Choices. Quarterly Journal of Economics, 129(3), 1409-1447.

Cárdenas, J. C., Dreber, A., Von Essen, E., \& Ranehill, E. (2012). Gender Differences in Competitiveness and Risk Taking: Comparing Children in Colombia and Sweden. Journal of Economic Behavior \&3 Organization, 83(1), 11-23.

Cavallaro, F. \& Rahman, T. (2009). The Santals of Bangladesh. Linguistics Journal, $4(2), 192-220$.

Chen, Y. \& Li, S. X. (2009). Group Identity and Social Preferences. American Economic Review, 99(1), 431-457.

Croson, R. \& Gneezy, U. (2009). Gender Differences in Preferences. Journal of Economic Literature, 47(2), 448-474.

Datta Gupta, N., Poulsen, A., \& Villeval, M. C. (2013). Gender Matching and Competitiveness: Experimental Evidence. Economic Inquiry, 51(1), 816-835.

D'Costa, B. (2014). Marginalization and Impunity: Violence Against Women and Girls in the Chittagong Hill Tracts. International Work Group for Indigenous Affairs.

Fantini, A. E. (2010). A Central Concern: Developing Intercultural Competence. In A. E. Fantini (Ed.), SIT Occasional Papers Series: Addressing Intercultural Education, Training 8 Service. SIT, Brattleboro, Vermont.

Fershtman, C. \& Gneezy, U. (2001). Discrimination in a Segmented Society: An Experimental Approach. Quarterly Journal of Economics, 116(1), 351-377.

Fiske, S. T., Dupree, C. H., Nicolas, G., \& Swencionis, J. K. (2016). Status, power, and intergroup relations: The personal is the societal. Current Opinion in Psychology, 11, $44-48$. 
Flory, J. A., Leibbrandt, A., \& List, J. A. (2014). Do Competitive Workplaces Deter Female Workers? A Large-Scale Natural Field Experiment on Job-Entry Decisions. Review of Economic Studies, 82(1), 122-155.

Geraldes, D. (2018). Women Dislike Competing Against Men. Working Paper.

Gneezy, U. \& Imas, A. (2016). Lab in the Field: Measuring Preferences in the Wild. In A. Banerjee \& E. Duflo (Eds.), Handbook of Field Experiments. Elsevier.

Gneezy, U., Leonard, K. L., \& List, J. A. (2009). Gender Differences in Competition: Evidence from a Matrilineal and a Patriarchal Society. Econometrica, 77(5), 16371664 .

Gneezy, U., Niederle, M., \& Rustichini, A. (2003). Performance in Competitive Environments: Gender Differences. Quarterly Journal of Economics, 118(3), 1049-1074.

Gneezy, U. \& Potters, J. (1997). An Experiment on Risk Taking and Evaluation Periods. Quarterly Journal of Economics, 122(2), 631-645.

Greenwald, A. G. \& Banaji, M. R. (1995). Implicit Social Cognition: Attitudes, SelfEsteem and Stereotypes. Psychological Review, 102(1), 4.

Hardiman, D. (1987). The Coming of the Devi: Adivasi Assertion in Western India. Oxford University Press.

Hoff, K. \& Pandey, P. (2006). Discrimination, Social Identity, and Durable Inequalities. American Economic Review, 96(2), 206-211.

Hoff, K. \& Pandey, P. (2014). Making Up People - The Effect of Identity on Performance in a Modernizing Society. Journal of Development Economics, 106, 118-131.

IMF (2013). Bangladesh: Poverty Reduction Strategy Paper 2013. IMF Country Report No. $13 / 63$.

Jost, J. T., Banaji, M. R., \& Nosek, B. A. (2004). A Decade of System Justification Theory: Accumulated Evidence of Conscious and Unconscious Bolstering of the Status Quo. Political Psychology, 25(6), 881-919.

Keltner, D., Gruenfeld, D. H., \& Anderson, C. (2003). Power, Approach, and Inhibition. Psychological Review, 110(2), 265.

Kijima, Y. (2006). Caste and Tribe Inequality: Evidence from India, 1983-1999. Economic Development and Cultural Change, 54 (2), 369-404. 
Leibbrandt, A., Gneezy, U., \& List, J. A. (2013). Rise and Fall of Competitiveness in Individualistic and Collectivistic Societies. Proceedings of the National Academy of Sciences, 110(23), 9305-9308.

Minimum Wage Board Bangladesh (2015). http://mwb.gov.bd/. Online; Accessed May $24,2016$.

Niederle, M. (2017). A Gender Agenda: A Progress Report on Competitiveness. American Economic Review: Papers $\&$ Proceedings, 107(5), 115-119.

Niederle, M., Segal, C., \& Vesterlund, L. (2013). How Costly is Diversity? Affirmative Action in Light of Gender Differences in Competitiveness. Management Science, 59(1), $1-16$.

Niederle, M. \& Vesterlund, L. (2007). Do Women Shy Away from Competition? Do Men Compete Too Much? Quarterly Journal of Economics, 122(3), 1067-1101.

Niederle, M. \& Vesterlund, L. (2011). Gender and Competition. Annual Review of Economics, 3(1), 601-630.

Orans, M. (1965). The Santal: A Tribe in Search of a Great Tradition. Wayne State University Press, Detriot, Michigan.

People's Republic of Bangladesh (2016). http://www.bangladesh.gov.bd/. Online; Accessed January 31, 2017.

Population Monograph of Bangladesh (2015). Population Density and Vulnerability: A Challenge for Sustainable Development of Bangladesh. Ministry of Planning.

Rao, V. (2001). Celebrations as Social Investments: Festival Expenditures, Unit Price Variation and Social Status in Rural India. Journal of Development Studies, 38(1), 71-97.

Reuben, E., Sapienza, P., \& Zingales, L. (2015). Taste for Competition and the Gender Gap Among Young Business Professionals. Working Paper.

Reuben, E., Wiswall, M., \& Zafar, B. (2017). Preferences and Biases in Educational Choices and Labour Market Expectations: Shrinking the Black Box of Gender. Economic Journal, 127(604), 2153-2186.

Risley, H. H. (1891). The Castes and Tribes of Bengal: Volume II. Harvard Library: Bengal Secretariat Press. 
Roy, R. D. (2012). Country Technical Notes on Indigenous Peoples' Issues: People's Republic of Bangladesh. IFAD Country Report.

Sachdev, I. \& Bourhis, R. Y. (1991). Power and Status Differentials in Minority and Majority Group Relations. European Journal of Social Psychology, 21(1), 1-24.

Samad, M. (2006). The Santals in Bangladesh: Problems, Needs and Development Potentials. Journal of Ethnic Affairs, 2, 9-13.

Sarker, P. \& Davey, G. (2009). Exclusion of Indigenous Children from Primary Education in the Rajshahi Division of Northwestern Bangladesh. International Journal of Inclusive Education, 13(1), 1-11.

Section 97 (1950). State Acquisition and Tenancy Act - East Bengal Act no. XXVIII of 1950. http://bdlaws.minlaw.gov.bd/pdf_part.php?id=241/.

Shah, A. (2007). The Dark Side of Indigeneity?: Indigenous People, Rights and Development in India. History Compass, 5(6), 1806-1832.

Shih, M., Pittinsky, T. L., \& Ambady, N. (1999). Stereotype Susceptibility: Identity Salience and Shifts in Quantitative Performance. Psychological Science, 10(1), 80-83.

Steele, C. M. \& Aronson, J. (1995). Stereotype Threat and the Intellectual Test Performance of African Americans. Journal of Personality and Social Psychology, 69(5), $797-811$.

Stoddard, O. \& Leibbrandt, A. (2014). An Experimental Study on the Relevance and Scope of Nationality as a Coordination Device. Economic Inquiry, 52(4), 1392-1407.

Sutter, M., Glätzle-Rützler, D., Balafoutas, L., \& Czermak, S. (2016). Cancelling Out Early Age Gender Differences in Competition: An Analysis of Policy Interventions. Experimental Economics, 19(2), 412-432.

Tajfel, H. (1982). Social Psychology of Intergroup Relations. Annual Review of Psychology, 33(1), 1-39.

Tajfel, H. (2010). Social Identity and Intergroup Relations. Cambridge University Press.

Tsutsui, K. \& Zizzo, D. J. (2014). Group Status, Minorities and Trust. Experimental Economics, 17(2), 215-244.

Upadhyay, V. S. \& Pandey, G. (1993). History of Anthropological Thought. Concept Publishing Company, New Delhi. 
Zhang, Y. J. (2013). Can Experimental Economics Explain Competitive Behavior Outside the Lab? Working Paper.

Zhang, Y. J. (2018). Culture, Institutions, and the Gender Gap in Competitive Inclination: Evidence from the Communist Experiment in China. Economic Journal (forthcoming). 


\section{Appendix A: Supplementary Tables}

Table 1: Perceived Probability of Winning

\begin{tabular}{|c|c|c|c|c|c|}
\hline & $\begin{array}{c}\text { Proportion of } \\
\text { Bengali } \\
\text { (Std. Dev. })\end{array}$ & $\begin{array}{c}\text { Proportion of } \\
\text { Santal } \\
(\text { Std. Dev. })\end{array}$ & $\begin{array}{c}\text { MW-test } \\
p \text {-values }\end{array}$ & $\begin{array}{l}\text { CS-test } \\
p \text {-values }\end{array}$ & $\mathbf{N}$ \\
\hline Perceived Probability of Winning & $\begin{array}{c}\mathbf{0 . 6 0} \\
(0.49)\end{array}$ & $\begin{array}{c}\mathbf{0 . 5 8} \\
(0.50)\end{array}$ & 0.798 & 0.798 & 252 \\
\hline Homogeneous & $\begin{array}{c}0.65 \\
(0.48)\end{array}$ & $\begin{array}{c}0.63 \\
(0.49)\end{array}$ & 0.850 & 0.849 & 120 \\
\hline Majority & $\begin{array}{c}0.52 \\
(0.51)\end{array}$ & $\begin{array}{c}0.57 \\
(0.50)\end{array}$ & 0.670 & 0.669 & 88 \\
\hline Minority & $\begin{array}{c}0.59 \\
(0.50)\end{array}$ & $\begin{array}{c}0.45 \\
(0.51)\end{array}$ & 0.371 & 0.365 & 44 \\
\hline Mixed & $\begin{array}{c}0.55 \\
(0.50)\end{array}$ & $\begin{array}{c}0.53 \\
(0.50)\end{array}$ & 0.862 & 0.861 & 132 \\
\hline \multicolumn{6}{|c|}{ Panel B: Compares Perceived Probability of Winning Within Ethnic Groups } \\
\hline & $\begin{array}{c}\text { Group } \\
\text { Treatment }\end{array}$ & & $\begin{array}{c}\text { Group } \\
\text { Treatment }\end{array}$ & $\begin{array}{c}\text { MW-test } \\
p \text {-values }\end{array}$ & $\begin{array}{c}\text { CS-test } \\
p \text {-values }\end{array}$ \\
\hline \multirow[t]{4}{*}{ Bengali } & Homogeneous & vs & Majority & 0.193 & 0.191 \\
\hline & Homogeneous & vs & Minority & 0.625 & 0.623 \\
\hline & Majority & vs & Minority & 0.603 & 0.600 \\
\hline & Homogeneous & $v s$ & Mixed & 0.234 & 0.232 \\
\hline \multirow[t]{4}{*}{ Santal } & Homogeneous & $v s$ & Majority & 0.504 & 0.502 \\
\hline & Homogeneous & vs & Minority & 0.148 & 0.145 \\
\hline & Majority & vs & Minority & 0.387 & 0.383 \\
\hline & Homogeneous & $v s$ & Mixed & 0.244 & 0.242 \\
\hline
\end{tabular}

Note: Mixed group combines perceived probability of winning of both Minority and Majority group treatments; $N$ is the total sample size, wherein ethnic groups are in equal proportions in each group composition; MW-test is the two sided Mann-Whitney U test; CS-test is the Pearson's Chi-squared test; Test $p$-values are comparing choices horizontally.

Table 2: Summary of Guessed Ranks

\begin{tabular}{|c|c|c|c|c|c|}
\hline $\begin{array}{l}\text { Experiment } \\
\text { Summary }\end{array}$ & $\begin{array}{c}\text { Mean Guessed Rank } \\
\text { of Bengali } \\
(S t d . \text { Dev. })\end{array}$ & $\begin{array}{c}\text { Mean Guessed Rank } \\
\text { of Santal } \\
(\text { Std. Dev. })\end{array}$ & $\begin{array}{c}\text { MW-test } \\
p \text {-values }\end{array}$ & $\begin{array}{l}\text { CS-test } \\
p \text {-values }\end{array}$ & $\mathbf{N}$ \\
\hline Guessed Rank & $\begin{array}{c}2.51 \\
(1.38)\end{array}$ & $\begin{array}{c}2.55 \\
(1.41)\end{array}$ & 0.867 & 0.834 & 252 \\
\hline Homogeneous & $\begin{array}{l}2.43 \\
(1.32)\end{array}$ & $\begin{array}{l}2.38 \\
(1.43)\end{array}$ & 0.656 & 0.806 & 120 \\
\hline Majority & $\begin{array}{c}2.66 \\
(1.48)\end{array}$ & $\begin{array}{c}2.52 \\
(1.41)\end{array}$ & 0.687 & 0.993 & 88 \\
\hline Minority & $\begin{array}{c}2.41 \\
(1.40)\end{array}$ & $\begin{array}{c}3.05 \\
(1.33)\end{array}$ & 0.093 & 0.012 & 44 \\
\hline Mixed & $\begin{array}{l}2.58 \\
(1.45)\end{array}$ & $\begin{array}{c}2.70 \\
(1.39)\end{array}$ & 0.544 & 0.315 & 132 \\
\hline
\end{tabular}

Note: 'Guessed Rank' is the relative guessed rank based on stage 2 performance, where 1 is the best and 6 is the worst; Mixed group combines ranks of both Minority and Majority group treatments; MW-test is the two sided Mann-Whitney U test; CS-test is the Pearson's Chi-squared test; Test $p$-values are comparing differences horizontally. 
Table 3: Performance Improvement from Stage 1 to Stage 2

\begin{tabular}{|c|c|c|c|c|c|}
\hline Groups & $\begin{array}{c}\text { Mean Score } \\
\text { in Stage } 1\end{array}$ & $\begin{array}{c}\text { Mean Score } \\
\text { in Stage } 2\end{array}$ & $\begin{array}{l}\text { SR-test } \\
p \text {-values }\end{array}$ & $\begin{array}{c}\text { T-test } \\
p \text {-values }\end{array}$ & $\mathbf{N}$ \\
\hline Pooled & $\begin{array}{c}23.93 \\
(7.19)\end{array}$ & $\begin{array}{c}25.97 \\
(7.36)\end{array}$ & 0.000 & 0.000 & 252 \\
\hline Bengali & $\begin{array}{c}24.10 \\
(7.67)\end{array}$ & $\begin{array}{c}25.73 \\
(7.71)\end{array}$ & 0.000 & 0.000 & 126 \\
\hline Homogeneous & $\begin{array}{l}21.72 \\
(6.51)\end{array}$ & $\begin{array}{l}23.78 \\
(6.35)\end{array}$ & 0.000 & 0.000 & 60 \\
\hline Majority & $\begin{array}{c}26.55 \\
(8.22)\end{array}$ & $\begin{array}{c}27.80 \\
(8.61)\end{array}$ & 0.144 & 0.121 & 44 \\
\hline Minority & $\begin{array}{c}25.68 \\
(7.85)\end{array}$ & $\begin{array}{c}26.91 \\
(8.23)\end{array}$ & 0.274 & 0.178 & 22 \\
\hline Mixed & $\begin{array}{c}26.26 \\
(8.05)\end{array}$ & $\begin{array}{c}27.5 \\
(8.44)\end{array}$ & 0.058 & 0.042 & 66 \\
\hline Santal & $\begin{array}{c}23.77 \\
(6.69)\end{array}$ & $\begin{array}{c}26.21 \\
(7)\end{array}$ & 0.000 & 0.000 & 126 \\
\hline Homogeneous & $\begin{array}{l}22.62 \\
(6.37)\end{array}$ & $\begin{array}{l}24.90 \\
(5.38)\end{array}$ & 0.000 & 0.000 & 60 \\
\hline Majority & $\begin{array}{c}24.52 \\
(6.87)\end{array}$ & $\begin{array}{l}27.45 \\
(7.86)\end{array}$ & 0.011 & 0.005 & 44 \\
\hline Minority & $\begin{array}{c}25.41 \\
(6.93)\end{array}$ & $\begin{array}{l}27.32 \\
(8.64)\end{array}$ & 0.039 & 0.112 & 22 \\
\hline Mixed & $\begin{array}{l}24.82 \\
(6.85)\end{array}$ & $\begin{array}{l}27.41 \\
(8.07)\end{array}$ & 0.002 & 0.001 & 66 \\
\hline
\end{tabular}

Note: 'Pooled' includes scores of both Bengali and Santal sample; Mixed group combines scores of both Minority and Majority group treatments; SR-test is the Wilcoxon signed-rank test; T-test is the paired T-test with equal variances. 
Table 4: Within Ethnic Group Treatment Effects on Willingness to Compete with Material Well-Being of Competitors as Controls

\begin{tabular}{|c|c|c|c|c|c|c|}
\hline \multirow[b]{3}{*}{ VARIABLES } & \multicolumn{6}{|c|}{ Panel A: Santal } \\
\hline & \multicolumn{3}{|c|}{ Averages of Competitors } & \multicolumn{3}{|c|}{ Number of Top $25 \%$} \\
\hline & (Income) & (Land) & (Both) & (Income) & (Land) & (Both) \\
\hline Santal-Majority & $\begin{array}{c}-0.255^{* *} \\
(0.111)\end{array}$ & $\begin{array}{c}-0.305^{* * *} \\
(0.102)\end{array}$ & $\begin{array}{c}-0.268^{* *} \\
(0.112)\end{array}$ & $\begin{array}{c}-0.291^{* * *} \\
(0.105)\end{array}$ & $\begin{array}{c}-0.319^{* * *} \\
(0.109)\end{array}$ & $\begin{array}{c}-0.320^{* * *} \\
(0.112)\end{array}$ \\
\hline Santal-Minority & $\begin{array}{c}-0.375^{* * *} \\
(0.097)\end{array}$ & $\begin{array}{c}-0.406^{* * *} \\
(0.095)\end{array}$ & $\begin{array}{c}-0.373^{* * *} \\
(0.106)\end{array}$ & $\begin{array}{c}-0.404^{* * *} \\
(0.092)\end{array}$ & $\begin{array}{c}-0.404^{* * *} \\
(0.092)\end{array}$ & $\begin{array}{c}-0.404^{* * *} \\
(0.093)\end{array}$ \\
\hline Average Income of Competitors & $\begin{array}{c}-0.001^{* * *} \\
(0.000)\end{array}$ & - & $\begin{array}{c}-0.001^{* * *} \\
(0.000)\end{array}$ & - & - & - \\
\hline Average Land of Competitors & - & $\begin{array}{c}-0.007^{* * *} \\
(0.003)\end{array}$ & $\begin{array}{c}-0.005^{* *} \\
(0.002)\end{array}$ & - & - & - \\
\hline No. of Top $25 \%$ Income & - & - & - & $\begin{array}{l}-0.041 \\
(0.051)\end{array}$ & - & $\begin{array}{c}0.001 \\
(0.061)\end{array}$ \\
\hline No. of Top $25 \%$ Land & - & - & - & - & $\begin{array}{l}-0.077 \\
(0.057)\end{array}$ & $\begin{array}{l}-0.077 \\
(0.068)\end{array}$ \\
\hline Other Controls & Yes & Yes & Yes & Yes & Yes & Yes \\
\hline Village Fixed Effects & Yes & Yes & Yes & Yes & Yes & Yes \\
\hline Observations & 125 & 125 & 125 & 125 & 125 & 125 \\
\hline Pseudo $R^{2}$ & 0.344 & 0.344 & 0.360 & 0.318 & 0.331 & 0.331 \\
\hline
\end{tabular}

Panel B: Bengali

\begin{tabular}{|c|c|c|c|c|c|c|}
\hline \multirow[b]{3}{*}{ VARIABLES } & \multirow{2}{*}{\multicolumn{3}{|c|}{ Averages of Competitors }} & \multirow{2}{*}{\multicolumn{3}{|c|}{ Number of Top $25 \%$}} \\
\hline & & & & & & \\
\hline & (Income) & (Land) & (Both) & (Income) & (Land) & (Both) \\
\hline Bengali-Majority & $\begin{array}{c}0.018 \\
(0.184)\end{array}$ & $\begin{array}{c}0.050 \\
(0.191)\end{array}$ & $\begin{array}{c}0.092 \\
(0.204)\end{array}$ & $\begin{array}{l}-0.005 \\
(0.183)\end{array}$ & $\begin{array}{c}-0.001 \\
(0.189)\end{array}$ & $\begin{array}{l}-0.009 \\
(0.191)\end{array}$ \\
\hline Bengali-Minority & $\begin{array}{c}0.113 \\
(0.223)\end{array}$ & $\begin{array}{c}0.194 \\
(0.229)\end{array}$ & $\begin{array}{c}0.233 \\
(0.239)\end{array}$ & $\begin{array}{c}0.091 \\
(0.212)\end{array}$ & $\begin{array}{c}0.090 \\
(0.240)\end{array}$ & $\begin{array}{c}0.078 \\
(0.232)\end{array}$ \\
\hline Average Income of Competitors & $\begin{array}{l}-0.000 \\
(0.001)\end{array}$ & - & $\begin{array}{l}-0.001 \\
(0.000)\end{array}$ & - & - & - \\
\hline Average Land of Competitors & - & $\begin{array}{c}0.004 \\
(0.003)\end{array}$ & $\begin{array}{l}0.005^{*} \\
(0.003)\end{array}$ & - & - & - \\
\hline No. of Top $25 \%$ Income & - & - & - & $\begin{array}{c}-0.014 \\
(0.020)\end{array}$ & - & $\begin{array}{l}-0.012 \\
(0.023)\end{array}$ \\
\hline No. of Top $25 \%$ Land & - & - & - & - & $\begin{array}{c}-0.011 \\
(0.050)\end{array}$ & $\begin{array}{c}-0.008 \\
(0.054)\end{array}$ \\
\hline Other Controls & Yes & Yes & Yes & Yes & Yes & Yes \\
\hline Village Fixed Effects & Yes & Yes & Yes & Yes & Yes & Yes \\
\hline Observations & 123 & 123 & 123 & 123 & 123 & 123 \\
\hline Pseudo $R^{2}$ & 0.191 & 0.199 & 0.206 & 0.191 & 0.190 & 0.191 \\
\hline
\end{tabular}

Robust standard errors clustered by sessions are in parentheses

$$
* * * \mathrm{p}<0.01,{ }^{* *} \mathrm{p}<0.05, * \mathrm{p}<0.1
$$

Note: Probit regressions with average marginal effects reported; dependent variable is "compete", which equals 1 when the individual opted to compete and 0 otherwise; 'Average Income (Land) of Competitors' is the average daily income (land possession) of all five group competitors; 'No. of Top $25 \%$ Income (Land)' is the number of competitors in a group whose income (land possession) is in the top $25 \%$ among all participants; 'Other Controls' include stages 1 and 2 scores, the perceived probability of winning, risk aversion, intercultural competence, income, profession, land possession, age, education, and having met other group members before; two villages were dropped in the Bengali data due to having single observations in each village. Table 1 in the paper describes all 'Other Controls'. 
Table 5: Summary of Choice across Different IC Competence

Panel A: Total Sample

\begin{tabular}{|c|c|c|c|c|c|c|}
\hline & $\begin{array}{c}\text { Above Median } \\
(S t d . \text { Dev. })\end{array}$ & $N_{A}$ & $\begin{array}{c}\text { Below Median } \\
(S t d . \text { Dev. })\end{array}$ & $N_{B}$ & $\begin{array}{c}\text { MW-test } \\
p \text {-values }\end{array}$ & $\begin{array}{c}\text { CS-test } \\
p \text {-values }\end{array}$ \\
\hline Bengali & $\begin{array}{c}0.43 \\
(0.50)\end{array}$ & 81 & $\begin{array}{c}0.24 \\
(0.43)\end{array}$ & 45 & 0.037 & 0.036 \\
\hline Santal & $\begin{array}{c}0.43 \\
(0.50)\end{array}$ & 92 & $\begin{array}{c}0.21 \\
(0.41)\end{array}$ & 34 & 0.019 & 0.018 \\
\hline \multicolumn{7}{|c|}{ Panel B: Mixed Groups Only } \\
\hline Bengali & $\begin{array}{c}0.53 \\
(0.50)\end{array}$ & 45 & $\begin{array}{c}0.24 \\
(0.44)\end{array}$ & 21 & 0.026 & 0.024 \\
\hline Santal & $\begin{array}{c}0.36 \\
(0.48)\end{array}$ & 58 & $\begin{array}{c}0.00 \\
(0.00)\end{array}$ & 8 & 0.041 & 0.039 \\
\hline \multicolumn{7}{|c|}{ Panel C: Homogeneous Groups Only } \\
\hline Bengali & $\begin{array}{c}0.31 \\
(0.36)\end{array}$ & 47 & $\begin{array}{c}0.25 \\
(0.44)\end{array}$ & 24 & 0.643 & 0.640 \\
\hline Santal & $\begin{array}{c}0.56 \\
(0.50)\end{array}$ & 34 & $\begin{array}{c}0.27 \\
(0.45)\end{array}$ & 26 & 0.026 & 0.025 \\
\hline
\end{tabular}

Note: Bengali (Santal) shows the proportion of Bengalis (Santals) who entered into competition; Above Median (Below Median) indicates if the intercultural competence level is above (below) the median score; MW-test is the two sided Mann-Whitney U test; CS-test is the Pearson's Chi-squared test; $N_{A}$ is the sample size that is above the median score and $N_{B}$ is the sample size that is below the median score. 


\section{Appendix B: Experimental Instructions}

\section{General Instructions}

Welcome to this study of decision making. The experiment will take about 60 minutes during which you will be asked to play some basic games. There will be three stages with three different instructions. But all instructions are very simple, and if you follow them carefully, you can earn a considerable amount of money. Out of these three stages, you will only be paid according to one stage, which will be determined at the end using a lottery. For showing up today you will receive 100 Takas. All the money you earn will be paid to you, privately and in cash, at the end after you complete a short exit survey. You will also be told how well you have scored in the payoff stage at the end, in private. This experiment will only be considered complete when you complete the exit survey. If you fail to complete the exit survey, then you will only receive the show-up fee.

The game is to separate lentils from a mix of rice and lentils, and then gather those separated lentils into an empty bowl. Each lentil separated will earn you money but each rice grain picked will lose you money. In short, lentils will win you money but rice will lose you money. So, you have to be careful not to separate rice along with lentils. There will be three stages and each stage will last for 60 seconds or 1 minute. Instructions for each stage are different and will be read aloud before each stage.

If you do not agree to take part in this experiment, then please raise your hand now. If you do not raise your hand, then we will assume you do not have any questions regarding the nature of this study and we will proceed to collect consents. If you do not want to participate, then you will only receive the show-up fee. Only people who participate will receive any money they earn during the experiment along with the show up fee.

Now, to better understand our instructions, we will readout some frequently asked questions and their answers to you. Please listen carefully.

- What do you need to separate from the mix, lentils or rice? [Answer: Lentils] 
- What will earn you money, lentils or rice? [Answer: Lentils]

- What will lose you money, lentils or rice? [Answer: Rice]

- How many stages does this experiment have? [Answer: Three]

- For how many stages will you be paid at the end? [Answer: One]

- How will the payment-stage be determined at the end of the experiment? [Answer: By a lottery]

- What do you have to do if you have a question or want to withdraw? [Answer: Raise hand]

- Will you receive money if you decide to leave? [Answer: No]

\section{Instruction: Stage 1}

In this stage, you will have to separate lentils from a mix of rice and lentils which is in the bowl right in front of you. You have to pick lentils and put it into the empty bowl. For each lentil separated, you will earn 5 Takas but, if you also separate rice and put it into the empty bowl, where you are supposed to keep lentils only, then you will lose 5 Takas for each grain of rice. In short, each lentil will earn you 5 Takas and each rice will lose you 5 Takas.

So, if you separate 2 lentils, you will get 10 Takas. If you separate 5 lentils, you will get 25 Takas. If you separate 10 lentils, you will get 50 Takas. But if you separate 10 lentils along with 1 grain of rice, you will get 45 Takas, because you lose 5 Takas for separating 1 grain of rice. If you separate 10 lentils along with 10 grains of rice, you will get 0 Takas or no money, because you lose 50 Takas for separating 10 grains of rice. If you separate 10 lentils along with 11 rice, you still get no money, because you cannot earn less than zero. Therefore, the more lentils you pick, the more money you will earn.

You have 60 seconds to complete this task. We will tell you when to start and when to stop performing the task. Please stop immediately when we ask you to stop. If you do not stop, then you will not earn anything from this stage.

Now, to better understand our instructions, we will readout some fre- 
quently asked questions and their answers to you. Please listen carefully.

- If you separate 10 lentils and no rice, what will be your final score? [Answer: 10]

- If you separate 10 lentils and 1 grain of rice, what will be your final score? [Answer: 9]

- If you separate 10 lentils and 10 grain of rice, what will be your final score? [Answer: 0]

- If you separate 10 lentils and 15 grain of rice, what will be your final score? [Answer: 0]

- How much will you earn per lentil? [Answer: 5 Takas]

- How much will you lose per grain of rice? [Answer: 5 Takas]

- What is the duration of this task? [Answer: 60 seconds]

Do you have any question?

This is the first of three stages, so there will be two more stages after this. At the end, there will be a lottery which will determine the payoff stage out of the three and you will be paid according to your score in that stage only. So, if the lottery determines this stage, then you will be paid according to this stage only. You will be paid in cash at the end. If you have any questions then please raise your hand now. If you do not, then we will proceed with the task.

\section{Instruction: Stage 2}

In this stage, you will have to separate lentils from a mix of rice and lentils, which is in the bowl right in front of you. You have to pick lentils and put it into the empty bowl. However, in this task, you will have to outperform all the other members in your group. That means you can only receive money if you pick more lentils than the other 5 members in your group. If you succeed to score the highest and win this task, then for each lentil separated, you will earn 30 Takas but if you also separate rice and put it in the empty bowl, where you are only supposed to keep lentils, then you will lose 30 Takas per grain of rice. In short, if you pick the most number of 
lentils, then each lentil will earn you 30 Takas. But if you cannot outperform your group members, then you will earn no money from this task. In case of a tie, the winning amount will be divided equally.

So, if you score the highest by picking 10 lentils, with all the other 5 members picking less than 10 lentils, then you will get 300 Takas and others will get no money. If you pick 10 lentils and 1 grain of rice and another member of your group picks 10 lentils but no rice, then it will mean that the other member has picked more lentils than you did, which means you lost the task and you will earn no money. That member, on the other hand, will win the task and will get 300 Takas with other members earning no money. If you score 11 lentils with 1 grain of rice and another member scores 10 lentils with no rice, then your score will be tied with that member and the winning amount will be divided equally. In this case, each tied winner will earn 150 Takas, with others earning no money at all.

Only the winner(s) will earn money, while the losers will get no money from this task. Therefore, the more lentils you pick compared to your group members, the higher your chances will be to win the task and earn 30 Takas per lentil.

You have 60 seconds to complete this task. We will tell you when to start and when to stop performing the task. Please stop immediately when we ask you to stop. If you do not stop, then you will not earn anything from this stage.

Now, to better understand our instructions, we will readout some frequently asked questions and their answers to you. Please listen carefully.

- Will you win the task if you pick the maximum number of lentils in your group? [Answer: Yes]

- Will you win the task if your group members pick more lentils than you? [Answer: No]

- What do you have to do to win this task and to win money? [Answer: Pick the highest number of lentils]

- If you separate 10 lentils and another group member separates 11 lentils, then who will win this task, you or your group member? [Answer: Group member] 
- If you score 10 lentils and all other group members score 9 lentils or less, then who will win this task, you or your group members? [Answer: You]

- If you separate 10 lentils and 1 grain of rice, what will be your final score? [Answer: 9]

- If you and another group member separate 10 lentils each, then what will happen to the winning money? [Answer: Money will be divided equally]

- How much will you earn per lentil if you win? [Answer: 30 Takas]

- How much will you lose per rice if you win? [Answer: 30 Takas]

- What is the duration of this task? [Answer: 60 seconds]

Do you have any questions?

\section{Instruction: Guessing Game}

Thank you for completing the first two stages of this experiment. An assistant will privately ask you, one by one, to go to the registration desk and guess your relative rank according to lentils you picked in your group in Stage 2. To guess your rank, you will be shown an image with 6 heads placed vertically and you will have to point out where you think you belong. For example, if you think you have picked the highest number of lentils in your group in Stage 2, then you will have to point to the head at the top. If you think you were the second best then point to the head below the top. Similarly, if you think you performed the worst, then point to the head at the bottom. If you guess correctly, that is, if your guess matches with your actual rank in Stage 2, then you will get 50 Takas. If your guess does not match with your actual score from Stage 2 then you will get no money.

Do you have any questions? If not, then please be seated. An assistant will privately ask you to go to the registration desk where you can make your guesses. 


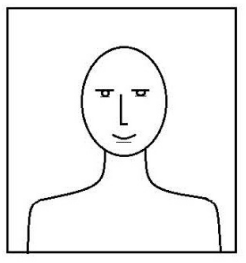

Rank 1

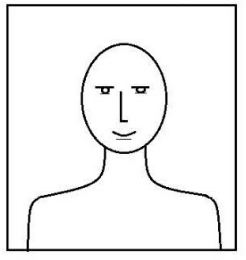

Rank 2

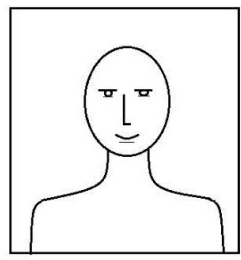

Rank 3

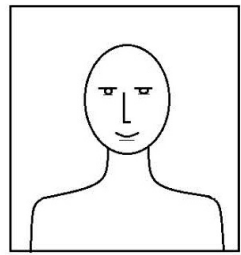

Rank 4
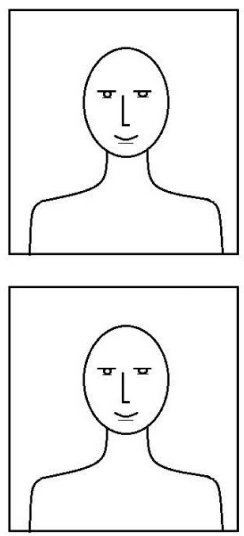

Rank 5

Rank 6

\section{Instruction: Stage 3}

In this stage, you will have to separate lentils from a mix of rice and lentils, which is in the bowl right in front of you. You have to pick lentils 
and put it into the empty bowl. However, before performing the task, we will now ask you to choose one of the two options according to which you wish to be paid in this stage. The two options are:

\section{Option 1:}

If you choose this option, you will get 5 Takas for each lentil you pick and lose 5 Takas for each rice grain you pick. So, this is exactly like the first task you completed. If you pick 2 lentils, then you will get 10 Takas. If you pick 10 lentils, then you will get 50 Takas. But if you pick 10 lentils along with 1 grain of rice, then you will get 45 Takas, because you lose 5 Takas for picking 1 grain of rice. Therefore, the more lentils you pick, the more money you will earn.

\section{Option 2:}

If you choose this option, you will only earn money if your score is higher than your group members' scores from Stage 2. If you succeed to surpass your group members' lentil count from Stage 2, then you will get 30 Takas for each lentil you pick but also you will lose 30 Takas for every rice you pick. If you do not manage to score higher than your group members' scores from Stage 2, then you will earn no money in this task. So, this is very much like the second task you completed, but now you will try to pick more lentils than what your group members picked in the second stage.

So, if you pick 10 lentils, which is also higher than all other 5 members' scores from Stage 2, then you will win this task and you will get 300 Takas. If you pick 10 lentils, which is not higher than all 5 group members' scores from Stage 2, then you will lose this task and you will not get any money. Therefore, the more lentils you pick compared to your group members' score

in Stage 2, the higher your chances will be to win the task and earn 30 Takas per lentil.

You have 60 seconds to complete this task. We will tell you when to start and when to stop performing the task. Please stop immediately when we ask you to stop. If you do not stop, you will not earn anything from this stage. 
Now, to better understand our instructions, we will readout some frequently asked questions and their answers to you. Please listen carefully.

- In which option do you earn 5 Takas per lentil? [Answer: Option 1]

- In which option do you need to score higher than your group members' score from Stage 2 in order to win money? [Answer: Option 2]

- In which option do you earn 30 Takas per lentil if you score higher than your group members' scores from Stage 2? [Answer: Option 2]

- If you choose Option 1, then how much will you earn per lentil? [Answer: 5 Takas]

- If you choose Option 2, and pick more lentils than your group members' scores from Stage 2, then how much will you earn per lentil? [Answer: 30 Takas]

- If you choose Option 2, and pick less lentils than your group members' scores from Stage 2, then will you win any money? [Answer: No]

- What is the duration of this task? [Answer: 60 seconds]

This is the final stage of this experiment. After this task, there will be a lottery which will determine the payoff stage and you will be paid according to your score in that stage only. You will be told how well you have performed in that stage and will be paid in cash at the end. If you have any questions, please raise your hand. If you do not, then we will proceed with the task.

Do you have any questions? If not, then an experimenter will ask you privately to go to the registration desk and make your choice on how you want to be paid: according to Option 1 or Option 2?

\section{Instruction: Risk Game}

Welcome to this study of decision-making. This is a bonus game which will take about 15 minutes. The instructions are simple, and if you follow them carefully, you can earn a considerable amount of money. All the money you earn is yours to keep and will be paid to you, in cash, immediately after the experiment ends. 
At the beginning of this experiment, you will receive 20 Takas. You are asked to choose the portion of this amount (between 0 and 20) that you wish to invest in a risky option. The rest of the money will be accumulated in your total balance.

The risky investment: there is an equal chance that the investment will fail or succeed. If the investment fails, you lose the amount you invested. If the investment succeeds, you receive 6 times the amount invested.

How do we determine if you win? After you have chosen how much you wish to invest, we will toss a coin to determine whether you win or lose. If the coin comes up heads, you win 6 times the amount you chose to invest. If the coin comes up tails, you lose the amount invested.

\section{Examples}

- If you choose to invest nothing, you will get the 20 Takas for sure. That is, the coin flip would not affect your profits.

- If you choose to invest all of the 20 Takas, then if the coin comes up heads, you win 120 Takas, and if the coin comes up tails, you win nothing and end up with 0 .

- If you choose to invest 10 Takas, then if the coin comes up heads, you win 70 Takas, and if the coin lands on tails, you end up with 10 Takas.

Do you have any questions? If not, then an experimenter will ask you privately to go to the registration desk and make your choice on how much you want to bet in the lottery. 